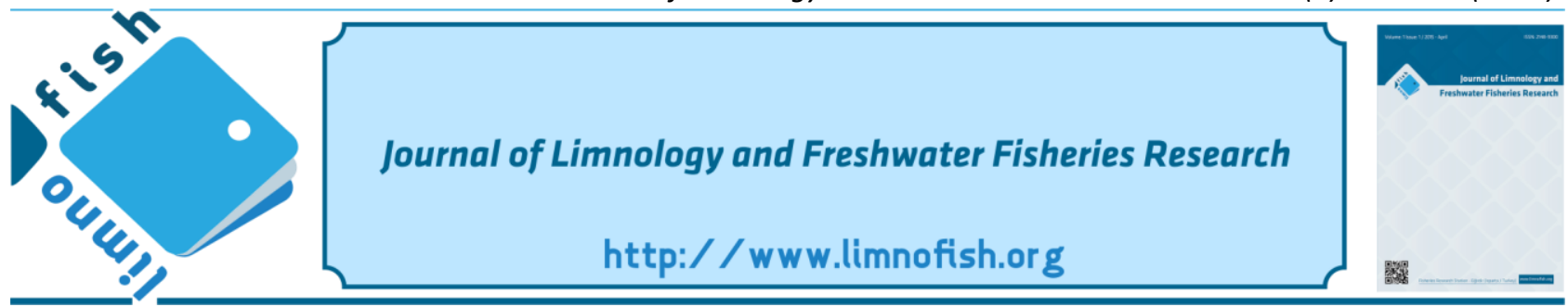

\title{
Yazır Gölü Havzası (Çavdır/BURDUR) Su Kaynaklarının Hidrojeokimyasal Özellikleri ve Su Kalitesinin Mevsimsel Değişimlerinin İncelenmesi
}

\author{
Simge VAROL ${ }^{1 *}$ (D) , Ilknur KÖSE ${ }^{1}$ \\ ${ }^{1}$ Süleyman Demirel Üniversitesi, Mühendislik Fakültesi, Jeoloji Mühendisliği Böl., 32260 Isparta-Türkiye
}

\section{$\ddot{o z}$}

Bu çalışmada Yazır Gölü havzası su kaynaklarındaki fizikokimyasal, majör iyon, ağır metal ve kirlilik parametreleri ile su kalitesinin mevsimsel değişimi incelenmiştir. Çalışma alanında alttan üstte doğru Yeşilbarak napı, Likya napları, paraallokton ve neootokton konumlu kaya birimleri yer almaktadır. Alüvyon ve kireçtaşı birimleri akifer birimlerdir. Kurak ve yağışlı mevsimlerde bölgeden toplam 30 su örneği toplanmıştır. Çalışma alanında $\mathrm{Ca}-\mathrm{Mg}-\mathrm{HCO}_{3}$ ve $\mathrm{Ca}-\mathrm{HCO}_{3}$ baskın su türleridir. Çalışma alanında ortaya çıkan farklı su tipleri ve kimyasal özelliklerindeki mevsimsel değişimlerde bölgedeki kayaçlarla temas süresi, suyun miktarı, sıcaklığı ve ortamın basıncı gibi faktörlerin etkili olduğu görülmektedir. Ayrıca su kaynaklarının hidrokimyasal ve kalitesini etkileyen diğer bir önemli faktörün tarımsal faaliyetlerle ilişkili antropojenik kirlenme olduğu tespit edilmiştir. Çalışmada kurak ve yağışlı dönem analiz sonuçları istatistiksel olarak da değerlendirilmiş ve parametrelerin birbirleri ile ilişkisi ortaya konmuştur. Çalışma alanındaki sulardan S4 ve S6 nolu örnekler WHO (2011), TSE266 (2005) standartlarına ve Schoeller diyagramına göre içilebilir özellik taşımamaktadır. Aynı şekilde çalışma alanındaki sular sulama suyu olarak değerlendirildiğinde ABD Tuzluluk Laboratuvarı ve Wilcox diyagramı sınıflamalarına göre de her iki dönemde de S4 ve S6 nolu örneklerin kullanımı sinırlıdır.
MAKALE BILGISI

\begin{tabular}{ll}
\hline \multicolumn{2}{l}{ ARAŞTIRMA MAKALESi } \\
$\begin{array}{ll}\text { Geliş } & : 18.03 .2020 \\
\text { Düzeltme } & : 31.05 .2020 \\
\text { Kabul } & : 03.06 .2020 \\
\text { Yayım } & : 29.12 .2020\end{array}$
\end{tabular}

DOI:10.17216/LimnoFish.705947

\section{* SORUMLU YAZAR}

simgevarol@sdu.edu.tr Tel : +902462111990

Anahtar kelimeler: Hidrojeoloji, hidrojeokimya, su kalitesi, Yazır Gölü

Investigation of Seasonal Changes of the Hydrogeochemical Properties and Water Quality of Water Resources within the Yazır Lake Basin (Çavdır / BURDUR)

\begin{abstract}
In this study, the physicochemical, major ion, heavy metal, and pollution parameters of the Yazır Lake basin water resources and the seasonal variation of the water quality were investigated. Yeşilbarak nappe, Lycian nappes, paraallokton and neootokton rock units are located from top to bottom in the region. Groundwater supplied from alluvium and limestone units. Thirty water samples were collected from the area in dry and wet seasons. Ca-Mg- $\mathrm{HCO}_{3}$ and $\mathrm{Ca}-\mathrm{HCO}_{3}$ were the dominant water types. The composition of the groundwater varies depending on such factors as the time of contact with the rocks, the amount of water, the temperature, and the pressures of the environment in the region. It has also been determined that another important factor affecting the hydrochemical and quality of water resources is anthropogenic pollution associated with agricultural activities. In this study, the results of the arid and rainy period analysis were evaluated statistically and the relationship of the parameters with each other was revealed. S4 and S6 samples from the waters in the study area are not potable according to WHO (2011), TSE266 (2005) standards, and Schoeller diagram. Similarly, when the waters in the study area are evaluated as irrigation water, according to the US Salinity Laboratory and Wilcox diagram classifications, the use of samples S4 and S6 is limited in both periods.
\end{abstract}

Keywords: Hydrogeology, hydrogeochemistry, water quality, Yazır Lake

Alıntılama

Varol S, Köse İ. 2020. Yazır Gölü Havzası (Çavdır/BURDUR) Su Kaynaklarının Hidrojeokimyasal Özellikleri ve Su Kalitesinin Mevsimsel Değişimlerinin İncelenmesi. LimnoFish. 6(3): 201-214. doi: 10.17216/LimnoFish.705947

\section{Giriş}

Nüfusun hızlı artışı ve buna paralel olarak artan tarımsal, içme kullanma ve sanayi suyu ihtiyaçları nedeni ile su kaynaklarına duyulan talep giderek artmaktadır. Talebin hızla artışına rağmen toprak ve su kaynakları kalite ve kantite olarak giderek daha çok kisıtlanmaktadır (Karadavut 2009; Akkan vd. 2018). Su kaynaklarının kirlenmesi önemli sosyoekonomik kayıplar getirmesinin yanı sıra, kirlilik türü ile kirliliğin yoğunluğuna bağlı olarak doğrudan 
insan ve ekosistem yaşamını tehdit etmektedir. Önümüzdeki yıllarda su varlığının daha da kısıtlı hale gelecek olması, aynı zamanda mevcut suyun kalitesi ile ilgili problem ve maliyetlerin de artmas1 beklenmektedir (WWAP 2012; Kiymaz vd. 2016). $\mathrm{Bu}$ nedenle su kalitesi, insan ve ekosistemin temel ihtiyaçlarının karşılanması için suyun miktarı kadar önemlidir. Bu amaçla kullanılan yeraltı ve yerüstü sularının kalitelerinin belirlenmesi, değişimlerinin izlenmesi ve çevreye olan etkilerinin bilinmesi toprak ve su kaynaklarının sürdürülebilirliği yönünden havza bazında su kaynakları yönetiminin önemini arttırmıştır. Havza yönetimi, su kaynaklarının sürdürülebilir kullanımının sağlanması için toprak, bitki örtüsü, diğer doğal kaynaklar ve insan kullanımlarının bütüncül bir yaklaşım içerisinde herkesin yararına uygun olacak şekilde korunması, geliştirilmesi ve yararlanılmasının sağlanmasıdır (Davraz vd. 2016; Mutlu ve Verep 2018). Bu amaçla su kaynaklarının korunması ve yönetimine ilişkin 23 Ekim 2000 tarihli ve 2000/60/EC say1l "Su Çerçeve Direktifi" yürürlüğe girmiştir. Bu direktifle (SÇD 2000) kirlilik kaynaklarının kaynaklarında engellenmesini ve tüm kirlilik kaynaklarının sürdürülebilir kontrolü için bir mekanizma oluşturulmasını gerektirmektedir. Direktif, yeraltı sularını da korumakta ve kalite ve kantitesi için kesin hedefler getirmektedir. Nehirler, göller ve kıyı suları için de kesin ekolojik hedefler getirmektedir (Chave 2001). Gerek direktifin ana hedefleri gerekse ortaya çıkan problemler su kaynakları yönetiminde suyun miktarının yanında, suyun kalitesine de önem verilmesi, su kalitesi izleme ve değerlendirilmesi çalışmalarına hız verilmesini gerektirmektedir. Özellikle son y1llarda endüstrileşmenin ve sanayinin gelişi ile beraber tarımsal mücadelede pestisit ve kimyasal ilaç kullanımından dolayı bu su kalitesindeki bozulmalara sıkça rastlanmaktadır. Sanayi artıkları, tarımsal ilaç atıkları ve endüstri, petrol, deri, deterjan atıkları su kimyasında özellikle balıklar ve su canlıları aleyhine önemli değişiklikler yapmakta ve bunların ölümlerine sebep olmaktadır (Sönmez vd. 2008; Sönmez vd. 2012). Bu tip kirlenme sonucunda yeraltı ve yer üstü suları kullanılamaz durumu gelmektedir. Özellikle yüzey sularında oksijen azlığına bağlı olarak su canlılarının ölümü, azot ve fosfor çoğalmasına bağlı olarak ötrofikasyon veya buna sebebiyet, suların yüzeylerinde biriken deterjan, yağ vb. gibi maddeler sonucunda suyun havalanmasını engellenir, güneş 1şınlarına engel olduğundan dolayı fotosentez düşer, kokuşma meydana gelir, estetik sorunlar ortaya çıkarır. Bulanıklık meydana getirdiği için balıkların besin bulmasını zorlaştırır, dolayısıyla büyümelerini yavaşlatır. Ağır metal birikimine sebebiyetten dolayı zehirlenmelere neden olabilir. Hiç şüphesiz ki kimyasal su kirliliğinin en tehlikeli boyutunu ağır metal birikimi oluşturur ve ağır metal birikimi canlı organizmalar için potansiyel birer tehlikedir (Rainbow 1995; Sönmez vd. 2012).

$\mathrm{Bu}$ çalışmada Burdur Gölü kapalı havzası içerisinde bulunan Yazır Gölü sulak alan alt havzası çalışma alanı olarak seçilmiştir. Çalışma alanındaki yüzey ve yeraltısuyu kaynakları bölgede başta içme suyu olmak üzere sulama ve kullanma gibi farkl1 amaçlar doğrultusunda kullanılmaktadır. Bu nedenle çalışmada havzadaki suların kalitesindeki mevsimsel değişimler incelenmiş ve bu değişimler istatistiksel yöntemlerle değerlendirilmiştir.

\section{Materyal ve Metot \\ Çalıșma Alanı}

Yazır Gölü sulak alanı (Çavdır/Burdur) Türkiye'nin güneybatısında yer almakta ve (Şekil 1) ve $194,78 \mathrm{~km}^{2}$, lik havza alanına sahiptir (Köse 2017). Genel olarak, sulak alan ve çevresinin iklimi, Orta Anadolu iklimi ve Akdeniz iklim bölgesinden etkilenmektedir. Çalışma alanına düşen ortalama yağıș miktarı 406,08 mm, ortalama buharlaşma miktarı ise 337,55 mm'dir (Köse 2017). Kocadere deresi çalışma alanındaki en önemli yüzey akışıdır. Ayrıca Yazır Gölü çalışma alanının ortasında yer almakta ve gölden sulama suyu temin edilmektedir. Çalışma alanı içerisinde bulunan yerleşim alanlarının içme suyu, çalışma alanındaki kaynak sularından temin edilmektedir. Ayrıca, sulama suları kuyu suyu ve yüzeysel akışlardan sağlanmaktadır (Varol ve Köse 2018a).

\section{Jeoloji-Hidrojeoloji}

Litolojik formasyonlar ve bu formasyonlarla suyun temas süresi, yüzey ve yeraltı sularının kimyasal bileşimini belirlemektedir. $\mathrm{Bu}$ nedenle öncelikle çalışma alanındaki jeolojik birimlerin litolojik özellikleri ve bunların hidrojeolojik özellikleri belirlenmiștir. Çalıșma alanındaki litolojik birimler iki grupta incelenmiştir. Bu birimler bölgeye otokton ve allokton olarak yerleşmiş birimlerdir (Köse 2017; Şekil 1; Tablo 1). Allokton birimler Marmaris peridotiti (Çapan 1980); Kızılcadağ ofiyolit ve melanj1 (Poisson 1977); Dolomitik kireçtaşları ve katmanlı çört üyelerinden oluşan Orhaniye formasyonu (Meşhur vd. 1989); Dutdere kireçtaş1 (Şenel vd. 1989; Bilgin vd. 1990); Kireçtaş1, kiltaşı ve kumtaşından oluşan Karanasıflar formasyonları (Şenel vd. 1989); Neritik ve dolomitik kireçtaşlarından oluşan Yuvadağ formasyonu; kireçtaş1, dolomitik kireçtaşı ve çörtlü kireçtaşından oluşan Çatlıca formasyonudur. Çalışma alanındaki otokton birimler ise kiltaşı, kumtaşı, konglomera ve kireçtaşından oluşan Çameli formasyonu (Erakman vd. 1982), alüvyon, yamaç molozu ve birikinti 
konisidir. Yazır Gölü sulak havzasının faaliyetlerle ilişkilidir (Koçyiğit vd. 2000; Varol ve jeolojik yapısının oluşumu genel olarak tektonik Köse 2018a).

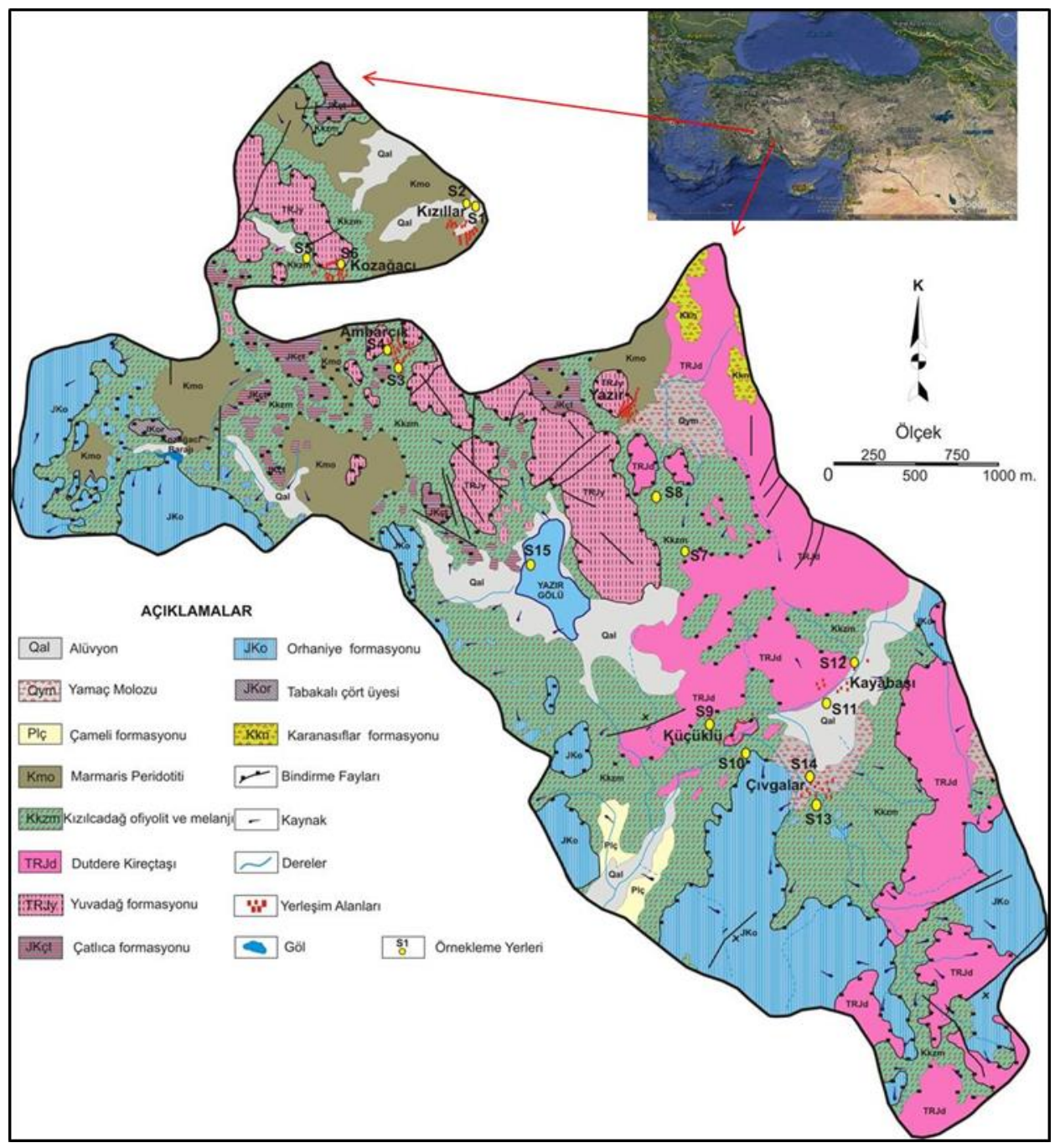

Şekil 1. Çalışma alanının yer bulduru ve jeoloji haritası.

Figure 1. Location and geology map of the study area.

Çalışma alanındaki litolojik birimler farklı hidrojeolojik özelliklere sahiptir. Bu birimler su tutma kabiliyetine göre geçirimsiz (akifüj), yarı geçirimli (akitard-1, akitard-2, akitard-3), geçirimli-1 (taneli akifer) ve geçirimli-2 (karstik akifer) olarak gruplandırılmıştır. Çalışmada benzer hidrojeolojik özelliklere sahip birimler aynı grupta toplanmıştır. $\mathrm{Bu}$ birimler ve özellikleri Tablo 1'de verilmiştir. Havzada önemli bir akifer olduğu düşünülen alüvyon, yaklaşık $34,84 \mathrm{~km}^{2}$ lik bir alana sahiptir ve taneli akifer olarak adlandırılmıştır. Karstik akifer ise çalışma alanındaki diğer önemli akifer türüdür. Çalışma alanındaki su kaynaklarının çoğu Kızılcadağ ofiyolit ve melanj içindeki olistolitlerden boşalmaktadır (Şekil 1) (Köse 2017). Çalışma alanındaki yeraltı suyu seviyesinin mevsimsel değişimi iki tür faktörle ilgilidir. Bunlar yağış, buharlaşma, yüzeysel akış gibi doğal faktörler ile yeraltı suyunun kuyulardan çekilmesi ve Kozağacı barajından sulama ile beslenim gibi yapay faktörlerdir. Çalışma alanındaki yeraltı suyunun ana beslenim kaynağı yağış sularıdır. Yeraltısuyunun statik seviyesi yapılan ölçümlerde Kasım 2016'da 3,70 ile 75,00 m ve Nisan 2017'de 1,00 ve 40,00 m arasında değiştiği tespit edilmiştir (Köse 2017; Varol ve Köse 2018a).

\section{Örnekleme ve Analizler}

Çalışma alanında Ekim 2016 (kurak dönem) ve Nisan 2017'de (yağışlı dönem) kuyulardan (5 örnek), kaynaklardan (8 örnek), dere (1 örnek) ve göl suyundan (1 örnek) olmak üzere toplam 30 su örneği başlıca kimyasal özelliklerinin belirlenmesi için analiz edilmiştir (Şekil 1). Havzada yüzey ve yeraltı sularının kimyasal özelliklerini belirlemek amacıyla çift kapaklı polietilen şişelere asitli $\left(\mathrm{HNO}_{3}\right)$ ve asitsiz olarak su örnekleri alınmıştır. Örnek alımı işlemleri sırasında YSI marka çok parametreli portatif su kalitesi ölçüm cihazı kullanılarak suların sıcaklık (T), elektriksel iletkenlik (EC), çözünmüş oksijen (DO), 
redoks potansiyeli (Eh) ve hidrojen iyonu konsantrasyonu $(\mathrm{pH})$ değerleri yerinde ölçülmüştür. $\mathrm{Su}$ örneklerinin anyon $\left(\mathrm{Cl}, \mathrm{SO}_{4}, \mathrm{HCO}_{3}, \mathrm{CO}_{3}\right)$, nitrat ve nitrit analizleri Hacettepe Üniversitesi Su Kimyası laboratuvarlarında, katyon ( $\mathrm{Na}, \mathrm{K}, \mathrm{Ca}$, $\mathrm{Mg}$ ) ve ağır metal analizleri (As, $\mathrm{Mn}, \mathrm{Fe}$ ) ACME (Kanada) laboratuvarında APHA (1998) ve WPCF (1995) standartlarına uygun şekilde yapılmıştır. Elde edilen sonuçlar farklı grafik ve diyagramlar kullanılarak değerlendirilmiştir. Bunun yanı sıra tüm matematiksel hesaplamalar Excel 2007 (Microsoft Office) kullanilarak fizikokimyasal değişkenler için hesaplanmıştır. Temel bileşenler istatistiksel analizi, SPSS yazılımı sürüm 15 kullanılarak analiz edilmiştir.

Tablo 1. Jeolojik birimlerin litostratigrafik ilişkileri ve hidrojeolojik özellikleri.

Table 1. Lithostratigraphic relations and hydrogeological properties of geological units.

\begin{tabular}{|c|c|c|c|}
\hline Yaş & Formasyon & Litoloji & Hidrojeolojik Özellikler \\
\hline Kuvaterner & Alüvyon (Qal) & Çakı1, kum ve çamurtaşı & $\begin{array}{c}\text { Geçirimli-1 } \\
\text { (Taneli Akifer) }\end{array}$ \\
\hline Kuvaterner & Yamaç Molozu (Qym) & $\begin{array}{c}\text { Tutturulmuş Çakı1, kum ve } \\
\text { çamurtaşı }\end{array}$ & $\begin{array}{c}\text { Geçirimli-1 } \\
\text { (Taneli Akifer) }\end{array}$ \\
\hline Pliyosen (Neojen) & Çameli formasyonu (Plç) & $\begin{array}{l}\text { Konglomera, kumtaşı, kiltaşı, killi } \\
\text { kireçtaşı, marn }\end{array}$ & $\begin{array}{l}\text { Yarı Geçirimli } \\
\text { (Akitard-1) }\end{array}$ \\
\hline $\begin{array}{l}\text { Apsiyen-Albiyen } \\
\text { (Kretase) }\end{array}$ & Marmaris peridotiti (Kmo) & $\begin{array}{c}\text { Peridotite, serpantinit ve } \\
\text { serpantinize peridotit }\end{array}$ & $\begin{array}{l}\text { Geçirimsiz } \\
\text { (Akifüj) }\end{array}$ \\
\hline $\begin{array}{l}\text { G. Senoniyen } \\
\text { (Kretase) }\end{array}$ & $\begin{array}{l}\text { Kızılcadağ Ofiyolit ve } \\
\text { Melanjı (Kkzm) }\end{array}$ & $\begin{array}{l}\text { Çört, diyabaz, bazalt, sipilit, tüf, } \\
\text { tüfit, gabro, ve ofiyolitik matriks } \\
\text { içinde serpantin blokları, olistolitler } \\
\text { içinde kireçtaşları, }\end{array}$ & $\begin{array}{l}\text { Yarı Geçirimli } \\
\text { (Akitard-3) }\end{array}$ \\
\hline O.-G. Triyas & Dutdere Kireçtaşı (TrJd) & Rekristalize kireçtaşları & $\begin{array}{c}\text { Geçirimli-2 } \\
\text { (Karstik Akifer) }\end{array}$ \\
\hline Jura- Kretase & $\begin{array}{l}\text { Orhaniye formasyonu } \\
\text { (JKo) }\end{array}$ & Kalsitürbidit, çörtlü kireçtaşı & $\begin{array}{l}\text { Yar1 Geçirimli } \\
\text { (Akitard-2) }\end{array}$ \\
\hline G. Eosen & $\begin{array}{l}\text { Karanasıflar formasyonu } \\
\qquad(\mathrm{Kkn})\end{array}$ & Neritik kireçtaş1 ve çörtlü breş & $\begin{array}{c}\text { Geçirimli-2 } \\
\text { (Karstik Akifer) }\end{array}$ \\
\hline Triyas- & $\begin{array}{l}\text { Yuvadağ formasyonu } \\
\text { (TRJy) }\end{array}$ & $\begin{array}{l}\text { Neritik kireçtaşı ve dolomitik } \\
\text { kireçtaşı }\end{array}$ & $\begin{array}{c}\text { Geçirimli-2 } \\
\text { (Karstik Akifer) }\end{array}$ \\
\hline Kretase & Çatlıca formasyonu (JKçt) & $\begin{array}{c}\text { Kireçtaşı, dolomitik kireçtaşı ve } \\
\text { çörtlü kireçtaşı }\end{array}$ & $\begin{array}{c}\text { Geçirimli-2 } \\
\text { (Karstik Akifer) }\end{array}$ \\
\hline
\end{tabular}

\section{Bulgular}

\section{Hidrojeokimya}

Yeraltısuyu kalitesi suyun içerisinde yer aldığı akifer kayaçların özellikleri ile ilişkilidir (Subramani vd. 2005; Kumar vd. 2016). Suyun kimyasal özellikleri ise evsel, endüstriyel veya tarımsal faaliyetlerde kullanım durumunu belirler. Günümüzde birçok gelişmiş ve gelişmekte olan ülkede görülen su kirliliği, hastalıkların ve bebek ölümlerinin en önemli faktörlerinden birisidir (Kumar vd. 2016). Bu çalışmada, Yazır Gölü havzasındaki yüzey ve yeraltı sularının fizikokimyasal, majör iyon ve kalite değerlendirmeleri yapılmış ve aşağıda başlıklar altında detaylandırılmıştır.
Fizikokimyasal Parametrelerin Mevsimsel Değișiminin Değerlendirmesi

Çalışma alanındaki kaynak sularının pH'ı kurak ve yağışlı dönemler için sırasıyla 8,96 (S12)-9,61 (S13) ve 8,93 (S12)-9,80 (S13) arasinda değişmektedir. Kuyulardan alınan su örneklerinin pH' lar1 kurak mevsimde 8,56 (S6)-9,22 (S2) ile yağışlı dönemde 8,54 (S6)-10,07 (S2) arasında ölçülmüştür. Ayrıca, yüzey sularından göl suyunun pH'1 kurak dönemde 9,27 (S15), dere suyunun pH'1 9,91 (S14)'dir. Yağışlı dönemde ise göl suyunun pH'1 9,53 (S15) dere suyunun pH'1 9,62 (S14) 'dir. Suların pH değerleri için yağışlı dönemde arttı̆̆ 1 görülmektedir (Tablo 2). Bu artış kayaçlar ile yağmur suyu arasındaki yüksek 
etkileşime bağlıdır (Makwe ve Chup 2013; Ngabirano vd. 2016).

Kaynak sularının EC değerleri kurak dönemde 183,4 (S13)-434,6 (S3) $\mu \mathrm{S} / \mathrm{cm}$ ile yağışı dönemde 139,3 (S13)-394,00 $\mu \mathrm{S} / \mathrm{cm} \quad$ (S12) arasında ölçülmüştür. Kuyu sularının EC değerleri kurak dönemde 119,2 (S6)-988,00 (S4) $\mu \mathrm{S} / \mathrm{cm}$ ve yağgşlı dönemde ise 293,7 (S10)-968,00 (S6) $\mu \mathrm{S} / \mathrm{cm}$ arasında değişmektedir. Ayrıca, yüzey sularından göl suyunun EC değerleri kurak dönemde (S15) 241,8 $\mu \mathrm{S} / \mathrm{cm}$, dere suyunun $253,7 \mu \mathrm{S} / \mathrm{cm}$ 'dir. Göl suyunun yağışlı dönemde EC değeri $253,7 \mu \mathrm{S} / \mathrm{cm}$ ve dere suyunun EC değeri $297,8 \mu \mathrm{S} / \mathrm{cm}$ aralığındadır (Tablo 2). Hem kurak hem de yağışlı dönemde sulardaki yüksek EC değerleri, yağmuru ile beslenmeyle ilişkili zenginleşme ve seyreltmenin mekansal değişkenliğini göstermiştir. Ayrıca, yağışı dönemde suların daha yüksek EC değerine sahip olması, kimyasal ayrışmanın yüksek olmasına ve akiferlerde yeraltı suyunun daha uzun kalış süresine bağlanabilir (Oinam vd. 2011; Alam vd. 2016; Varol ve Köse 2018b).

Suların kalitesini belirleyen fizikokimyasal parametrelerden biri olan sicaklık değerlerinin mevsimsel değişimleri de bu çalışmada incelenmiştir. Buna göre kaynak sularının $\mathrm{T}\left({ }^{\circ} \mathrm{C}\right)$ değerleri kurak dönemde 11,9 (S12)-17,3 ${ }^{\circ} \mathrm{C}(\mathrm{S} 3)$ ve yağışlı dönemde 9,2 (S13)-13,4 ${ }^{\circ} \mathrm{C}(\mathrm{S} 7)$ aralığında ölçülmüştür. Kuyu sularının $\mathrm{T}\left({ }^{\circ} \mathrm{C}\right)$ değerleri ise kurak dönemde 11,4 (S10)-17,5 ${ }^{\circ} \mathrm{C}$ (S6) ve yağışlı dönemde $\quad 11,0 \quad(\mathrm{~S} 8)-12,5 \quad{ }^{\circ} \mathrm{C} \quad(\mathrm{S} 4)$ arasinda değişmiştir. Çalışma alanındaki yüzey sularından göl suyunun $\mathrm{T}\left({ }^{\circ} \mathrm{C}\right)$ değerleri kurak dönemde $\quad 11,8 \quad{ }^{\circ} \mathrm{C} \quad(\mathrm{S} 15)$ ve dere suyunun $12,4{ }^{\circ} \mathrm{C}$ (S14)'dir. Yağışlı dönemde ise göl suyu 9,4 ${ }^{\circ} \mathrm{C}$ (S15) ve dere suyu $11,2{ }^{\circ} \mathrm{C}$ (S14) olarak ölçülmüştür (Tablo 2). Çalışma alanındaki suların kurak ve yağışlı dönemlerdeki sıcaklık değişimleri meteorolojik koşullarla ilişkilidir.

Yükseltgenme-indirgeme potansiyeli (ORP), bir maddenin başka bir maddeyi oksitleme veya azaltma derecesini gösteren bir ölçümdür. Buna bağlı olarak su kimyası ve Arsenik türlerini suda ölçülen ORP değerleri ile belirlemek de mümkündür (APHA 1998). Bu çalışmada, kaynak sularında ORP değerleri kurak dönemde $327,00 \mathrm{mV}$ (S5)-620,90 mV (S13) yağışlı dönemde ise 240,3 mV (S1) ile $348,00 \mathrm{mV}$ (S3) arasında bulunmuştur. Kuyu sularından alınan örneklerin ORP değerleri kurak dönemde 320,2 mV (S2)-370,1 mV ve yağışlı dönemde ise $208 \mathrm{mV}$ (S2)-325,6 mV
(S6) arasında değişmektedir. Ayrıca, yüzey sularından göl suyunun ORP değeri kurak dönemde $338,9 \mathrm{mV}$ (S15) dere suyunda 410,9 mV (S14) ölçülmüştür. Yağışlı dönemde ise göl suyunun ORP değeri 288,9 mV (S15) ve dere suyunun ORP değeri 295,5 mV (S14) olarak ölçülmüştür (Tablo 2) (Varol ve Köse 2018b).

\section{Majör İyonların Mevsimsel Değişiminin Değerlendirmesi}

Çalışma alanındaki yeraltısularında en yaygın iyon $\mathrm{Ca}$ iyonudur. Daha sonra ise, bileşiminde daha az miktarda $\mathrm{Mg}$, $\mathrm{Na}$ ve $\mathrm{K}$ iyonları bulunur (Tablo 3). Buna göre, su örneklerine ait majör iyonların mevsimsel dizilimleri Tablo 3' de sunulmuştur. Sudaki $\mathrm{Ca}$ ve $\mathrm{Mg}$ iyonu kaynakları genellikle kireçtaşı ve dolomitik kireçtaşı gibi karbonat bakımından zengin kayaçlardır. $\mathrm{Bu}$ tür kayaçlardaki karbonatlar, yeraltısuyuna sulama ve yağış gibi çeşitli yollarla karışmaktadır. $\mathrm{Mg}$ iyonundaki artış kurak ve yağışlı dönemlerde, özellikle Kızılcadağ ofiyolit ve melanjı içerisinden boşalan kaynak sularında (S1, S4 ve S15) gözlenmiştir. Yeraltısularındaki $\mathrm{Mg}$ iyonu kaynağı, su ile kayaçların bileşiminde bulunan minerallerin iyon değişimidir. $\mathrm{K}$ iyonu açısından kurak dönemde sadece Kızılcadağ ofiyolit ve melanjı ile tabakalı çört üyesi dokanağından boşalmakta olan Ambarcık kaynak suyunda (S3) bir artış gözlemlenmiştir. $\mathrm{Bu}$ artış, kayaç-su etkileşimine bağlı iyon değişiminden kaynaklanmaktadır.

Çalışma alanındaki yeraltısuyu örneklerinin majör anyonik bileşeni olan Bikarbonat $\left(\mathrm{HCO}_{3}\right)$ iyon konsantrasyonu kurak dönemde 115,61-505,43 $\mathrm{mg} / \mathrm{L}$, yağı̧̧1 dönemde ise 148,05-538,93 $\mathrm{mg} / \mathrm{L}$ arasında değişmektedir. Alkalinitenin ana kaynağ1 olan $\mathrm{HCO}_{3}$ genellikle $\mathrm{CO}_{2}$ ve karbonatların çözünmesi, silikatların karbonik asit ile reaksiyonu (Ranjan vd. 2013) ve organik maddenin oksidasyonu (Jeong 2001) ile ilişkilidir. Dutdere kireçtaş1 ve Kızılcadağ ofiyolit ve melanj1 dokanağından boşalım gösteren yeraltısuyu örneklerinin çoğunda $\mathrm{Cl}$ konsantrasyonlarının kurak dönemde arttığı görülmektedir. $\mathrm{Cl}$ konsantrasyonlarındaki bu artış Kızılcadağ ofiyolit ve melanjı ile yağmur suyu arasındaki kayasu etkileşimi ile ilişkilendirilmiştir. Çalışma alanındaki örneklerdeki sülfitin oksidasyonundan kaynaklanan sülfat $\left(\mathrm{SO}_{4}\right)$ (Ranjan vd. 2013) kurak dönemde 3,11-70,99 mg/L ve yağışlı dönemde ise 2,13-83,79 $\mathrm{mg} / \mathrm{L}$ arasında değişmektedir. 
Tablo 2. Kurak ve yağışlı dönemler için su örneklerinin fizikokimyasal, majör iyon ve ağır metal konsantrasyonlarının tanımlayıcı istatistiksel analiz sonuçları.

Table 2. Descriptive statistical analysis results of physicochemical, major ion and heavy metal concentrations of water samples for dry and wet periods.

\begin{tabular}{|c|c|c|c|c|c|c|c|c|c|c|c|c|}
\hline \multirow[b]{3}{*}{$\mathbf{T}$} & \multirow[b]{2}{*}{ Birim } & \multicolumn{5}{|c|}{ Kurak Dönem } & \multicolumn{4}{|c|}{ Yağışlı Dönem } & \multirow[b]{2}{*}{$\begin{array}{l}\text { WHO } \\
(2011)\end{array}$} & \multirow[b]{2}{*}{$\begin{array}{c}\text { TSE 266 } \\
\text { (2005) }\end{array}$} \\
\hline & & $\mathrm{N}$ & Min. & Mak. & Ort. & $\begin{array}{l}\text { Std. } \\
\text { Sap. }\end{array}$ & Min. & Mak. & Ort. & $\begin{array}{l}\text { Std. } \\
\text { Sap. }\end{array}$ & & \\
\hline & ${ }^{\circ} \mathrm{C}$ & 15 & 11,40 & 17,50 & 13,90 & 2,11 & 9,20 & 13,40 & 11,20 & 1,15 & & \\
\hline pH & & 15 & 8,56 & 9,91 & 9,14 & 0,36 & 8,54 & 10,07 & 9,29 & 0,41 & $6,5-8,5$ & $6,5-9,5$ \\
\hline ORP & $\mathrm{mV}$ & 15 & 320,20 & 620,90 & 400,19 & 100,85 & 208,00 & 348,00 & 297,22 & 34,50 & & \\
\hline EC & $\mu \mathrm{S} / \mathrm{cm}$ & 15 & 119,20 & 988,00 & 335,34 & 201,44 & 139,30 & 968,00 & 382,32 & 248,21 & & \\
\hline TDS & $\mathrm{mg} / \mathrm{L}$ & 15 & 77,48 & 642,20 & 217,97 & 130,93 & 90,55 & 629,20 & 248,51 & 161,33 & 500 & \\
\hline $\mathbf{C a}$ & $\mathrm{mg} / \mathrm{L}$ & 15 & 37,56 & 134,88 & 64,77 & 30,17 & 35,99 & 130,82 & 62,09 & 27,93 & 300 & 200 \\
\hline Mg & $\mathrm{mg} / \mathrm{L}$ & 15 & 2,79 & 80,43 & 28,51 & 22,13 & 1,51 & 79,71 & 30,84 & 25,81 & 30 & 150 \\
\hline $\mathrm{Na}$ & $\mathrm{mg} / \mathrm{L}$ & 15 & 2,31 & 63,40 & 11,03 & 16,20 & 1,03 & 54,87 & 10,24 & 14,59 & 200 & 200 \\
\hline $\mathbf{K}$ & $\mathrm{mg} / \mathrm{L}$ & 15 & 0,33 & 52,52 & 4,09 & 13,40 & 0,22 & 43,53 & 3,48 & 11,08 & & 12 \\
\hline $\mathrm{HCO}_{3}$ & $\mathrm{mg} / \mathrm{L}$ & 15 & 115,61 & 505,43 & 259,45 & 105,01 & 148,05 & 538,93 & 302,82 & 110,68 & 500 & \\
\hline $\mathrm{CO}_{3}$ & $\mathrm{mg} / \mathrm{L}$ & 15 & 0,00 & 22,86 & 8,38 & 10,77 & 0,00 & 23,30 & 5,82 & 8,80 & & \\
\hline $\mathrm{Cl}$ & $\mathrm{mg} / \mathrm{L}$ & 15 & 2,04 & 71,14 & 11,32 & 20,04 & 1,41 & 79,96 & 12,91 & 22,366 & 250 & 250 \\
\hline $\mathrm{SO}_{4}$ & $\mathrm{mg} / \mathrm{L}$ & 15 & 2,19 & 70,99 & 14,00 & 20,40 & 2,13 & 83,79 & 16,97 & 23,52 & 250 & 250 \\
\hline $\mathrm{NO}_{3}$ & $\mathrm{mg} / \mathrm{L}$ & 15 & 0,00 & 263,80 & 32,53 & 75,26 & 0,77 & 258,49 & 35,59 & 78,66 & 50 & 50 \\
\hline $\mathrm{NO}_{2}$ & $\mathrm{mg} / \mathrm{L}$ & 15 & 0,00 & 0,35 & 0,03 & 0,08 & 0,00 & 0,00 & 0,00 & 0,00 & 3 & 0,05 \\
\hline $\mathbf{N H}_{4}$ & $\mathrm{mg} / \mathrm{L}$ & 15 & 0,00 & 2,56 & 0,49 & 0,63 & 0,00 & 0,12 & 0,02 & 0,04 & $0,05-0,50$ & $0,05-0,50$ \\
\hline As & $\mathrm{mg} / \mathrm{L}$ & 15 & 0,02 & 0,08 & 0,06 & 0,02 & 0,04 & 0,13 & 0,09 & 0,02 & 0,01 & 0,01 \\
\hline Mn & $\mathrm{mg} / \mathrm{L}$ & 15 & 0,00 & 0,35 & 0,03 & 0,09 & 0,01 & 0,09 & 0,05 & 0,02 & - & 0,05 \\
\hline $\mathbf{F e}$ & $\mathrm{mg} / \mathrm{L}$ & 15 & 0,00 & 5,52 & 0,39 & 1,42 & 0,01 & 0,30 & 0,05 & 0,07 & - & 0,2 \\
\hline $\mathbf{N}$ & & 15 & & & & & & & & & & \\
\hline
\end{tabular}

Tablo 3. Su örneklerinin yeri ve ana iyon dizileri (Köse 2017).

Table 3. Location of water samples and main ion sequences (Köse 2017).

\begin{tabular}{|c|c|c|c|c|c|c|}
\hline \multirow[b]{2}{*}{ Örnek Yeri } & \multirow[b]{2}{*}{ No } & \multirow[b]{2}{*}{ Örnek Tipi } & \multicolumn{2}{|c|}{ Kurak Dönem (Ekim 2016) } & \multicolumn{2}{|c|}{ Yağ1şl1 Dönem (Nisan 2017) } \\
\hline & & & Katyon Dizisi & Anyon Dizisi & Katyon Dizisi & Anyon Dizisi \\
\hline Kızıllar & S1 & Kaynak & $\mathrm{Mg}>\mathrm{Ca}>\mathrm{Na}>\mathrm{K}$ & $\mathrm{HCO}_{3}>\mathrm{Cl}>\mathrm{SO}_{4}>\mathrm{CO}_{3}$ & $\mathrm{Mg}>\mathrm{Ca}>\mathrm{Na}>\mathrm{K}$ & $\mathrm{HCO}_{3}>\mathrm{SO}_{4}>\mathrm{CO}_{3}>\mathrm{Cl}$ \\
\hline Kızıllar & S2 & S.Kuyu & $\mathrm{Ca}>\mathrm{Mg}>\mathrm{Na}>\mathrm{K}$ & $\mathrm{HCO}_{3}>\mathrm{Cl}>\mathrm{SO}_{4}>\mathrm{CO}_{3}$ & $\mathrm{Mg}>\mathrm{Ca}>\mathrm{Na}>\mathrm{K}$ & $\mathrm{HCO}_{3}>\mathrm{CO}_{3}>\mathrm{Cl}>\mathrm{SO}_{4}$ \\
\hline Ambarcık & S3 & Kaynak & $\mathrm{K}>\mathrm{Mg}>\mathrm{Ca}>\mathrm{Na}$ & $\mathrm{HCO}_{3}>\mathrm{Cl}>\mathrm{SO}_{4}>\mathrm{CO}_{3}$ & $\mathrm{Ca}>\mathrm{Mg}>\mathrm{Na}>\mathrm{K}$ & $\mathrm{HCO}_{3}>\mathrm{CO}_{3}>\mathrm{Cl}>\mathrm{SO}_{4}$ \\
\hline Ambarcık & $\mathbf{S 4}$ & S.Kuyu & $\mathrm{Mg}>\mathrm{Ca}>\mathrm{Na}>\mathrm{K}$ & $\mathrm{HCO}_{3}>\mathrm{Cl}>\mathrm{SO}_{4}>\mathrm{CO}_{3}$ & $\mathrm{Mg}>\mathrm{Ca}>\mathrm{Na}>\mathrm{K}$ & $\mathrm{HCO}_{3}>\mathrm{Cl}>\mathrm{SO}_{4}>\mathrm{CO}_{3}$ \\
\hline Kozağacı & S5 & Kaynak & $\mathrm{Ca}>\mathrm{Mg}>\mathrm{Na}>\mathrm{K}$ & $\mathrm{HCO}_{3}>\mathrm{Cl}>\mathrm{SO}_{4}>\mathrm{CO}_{3}$ & $\mathrm{Ca}>\mathrm{Mg}>\mathrm{Na}>\mathrm{K}$ & $\mathrm{HCO}_{3}>\mathrm{SO}_{4}>\mathrm{Cl}>\mathrm{CO}_{3}$ \\
\hline Kozağacı & S6 & S.Kuyu & $\mathrm{Ca}>\mathrm{Mg}>\mathrm{Na}>\mathrm{K}$ & $\mathrm{HCO}_{3}>\mathrm{Cl}>\mathrm{SO}_{4}>\mathrm{CO}_{3}$ & $\mathrm{Ca}>\mathrm{Mg}>\mathrm{Na}>\mathrm{K}$ & $\mathrm{HCO}_{3}>\mathrm{Cl}>\mathrm{SO}_{4}>\mathrm{CO}_{3}$ \\
\hline Gölcük (Yazır) & S7 & Kaynak & $\mathrm{Ca}>\mathrm{Mg}>\mathrm{Na}>\mathrm{K}$ & $\mathrm{HCO}_{3}>\mathrm{Cl}>\mathrm{SO}_{4}>\mathrm{CO}_{3}$ & $\mathrm{Ca}>\mathrm{Mg}>\mathrm{Na}>\mathrm{K}$ & $\mathrm{HCO}_{3}>\mathrm{Cl}>\mathrm{SO}_{4}>\mathrm{CO}_{3}$ \\
\hline Gölcük (Yazır) & S8 & S.Kuyu & $\mathrm{Ca}>\mathrm{Mg}>\mathrm{Na}>\mathrm{K}$ & $\mathrm{HCO}_{3}>\mathrm{Cl}>\mathrm{SO}_{4}>\mathrm{CO}_{3}$ & $\mathrm{Mg}>\mathrm{Ca}>\mathrm{Na}>\mathrm{K}$ & $\mathrm{HCO}_{3}>\mathrm{SO}_{4}>\mathrm{Cl}>\mathrm{CO}_{3}$ \\
\hline Küçüklü & S9 & Kaynak & $\mathrm{Ca}>\mathrm{Mg}>\mathrm{Na}>\mathrm{K}$ & $\mathrm{HCO}_{3}>\mathrm{CO}_{3}>\mathrm{Cl}>\mathrm{SO}_{4}$ & $\mathrm{Ca}>\mathrm{Mg}>\mathrm{Na}>\mathrm{K}$ & $\mathrm{HCO}_{3}>\mathrm{Cl}>\mathrm{SO}_{4}>\mathrm{CO}_{3}$ \\
\hline Küçüklü & S10 & S.Kuyu & $\mathrm{Ca}>\mathrm{Mg}>\mathrm{Na}>\mathrm{K}$ & $\mathrm{HCO}_{3}>\mathrm{Cl}>\mathrm{SO}_{4}>\mathrm{CO}_{3}$ & $\mathrm{Ca}>\mathrm{Mg}>\mathrm{Na}>\mathrm{K}$ & $\mathrm{HCO}_{3}>\mathrm{SO}_{4}>\mathrm{Cl}>\mathrm{CO}_{3}$ \\
\hline Kayabaş & S11 & Kaynak & $\mathrm{Ca}>\mathrm{Mg}>\mathrm{Na}>\mathrm{K}$ & $\mathrm{HCO}_{3}>\mathrm{CO}_{3}>\mathrm{Cl}>\mathrm{SO}_{4}$ & $\mathrm{Ca}>\mathrm{Mg}>\mathrm{Na}>\mathrm{K}$ & $\mathrm{HCO}_{3}>\mathrm{SO}_{4}>\mathrm{Cl}>\mathrm{CO}_{3}$ \\
\hline Kayabaş & S12 & Kaynak & $\mathrm{Ca}>\mathrm{Mg}>\mathrm{Na}>\mathrm{K}$ & $\mathrm{HCO}_{3}>\mathrm{CO}_{3}>\mathrm{Cl}>\mathrm{SO}_{4}$ & $\mathrm{Ca}>\mathrm{Mg}>\mathrm{Na}>\mathrm{K}$ & $\mathrm{HCO}_{3}>\mathrm{SO}_{4}>\mathrm{Cl}>\mathrm{CO}_{3}$ \\
\hline Çivgalar & S13 & Kaynak & $\mathrm{Ca}>\mathrm{Mg}>\mathrm{Na}>\mathrm{K}$ & $\mathrm{HCO}_{3}>\mathrm{CO}_{3}>\mathrm{Cl}>\mathrm{SO}_{4}$ & $\mathrm{Ca}>\mathrm{Mg}>\mathrm{Na}>\mathrm{K}$ & $\mathrm{HCO}_{3}>\mathrm{SO}_{4}>\mathrm{Cl}>\mathrm{CO}_{3}$ \\
\hline Çıvgalar & S14 & Dere & $\mathrm{Ca}>\mathrm{Mg}>\mathrm{Na}>\mathrm{K}$ & $\mathrm{HCO}_{3}>\mathrm{CO}_{3}>\mathrm{Cl}>\mathrm{SO}_{4}$ & $\mathrm{Ca}>\mathrm{Mg}>\mathrm{Na}>\mathrm{K}$ & $\mathrm{HCO}_{3}>\mathrm{CO}_{3}>\mathrm{SO}_{4}>\mathrm{Cl}$ \\
\hline Yazır Gölü & S15 & Göl & $\mathrm{Mg}>\mathrm{Ca}>\mathrm{Na}>\mathrm{K}$ & $\mathrm{HCO}_{3}>\mathrm{CO}_{3}>\mathrm{Cl}>\mathrm{SO}_{4}$ & $\mathrm{Mg}>\mathrm{Ca}>\mathrm{Na}>\mathrm{K}$ & $\mathrm{HCO}_{3}>\mathrm{CO}_{3}>\mathrm{SO}_{4}>\mathrm{Cl}$ \\
\hline
\end{tabular}

Ăgır Metal ve Kirlilik Parametrelerinin Mevsimsel Değişiminin Değerlendirmesi

Çalışma alanındaki su kaynaklarından alınan örneklerde sularda özellikle kirlilik göstergesi olan ve belirli miktarlardan fazla olması durumunda kullanılmasını sinırlandiran kimyasal parametrelerden $\mathrm{NO}_{3}, \mathrm{NO}_{2}, \mathrm{NH}_{4}$ yanı sira As, Fe ve $\mathrm{Mn}$ analizleri de yaptırılmıştır. $\mathrm{NO}_{3}{ }^{-}$ konsantrasyonlar1 kurak dönemde $0-263,80 \mathrm{mg} / \mathrm{L}$ ve yağışlı dönemde $0,77-258,49 \mathrm{mg} / \mathrm{L}$ arasında değişmektedir. $\mathrm{NO}_{2}$ konsantrasyonları kurak dönemde $0-0,35 \mathrm{mg} / \mathrm{L}$ ve yağışlı dönemde sularda bulunmamaktadır. $\mathrm{NH}_{4}$ konsantrasyonları ise $0-2,56$ $\mathrm{mg} / \mathrm{L}$ ve yağışlı dönemde $0-0,12 \mathrm{mg} / \mathrm{L}$ arasında değişmektedir. Sularda $\mathrm{NO}_{3}, \mathrm{NO}_{2}$ ve $\mathrm{NH}_{4}$ tarımsal faaliyetlerden kaynaklanan kirliliğin göstergesidir. Özellikle içme suyu olarak kullanılan sularda WHO (2011) ve TSE266 (2005) tarafindan belirlenen sinır değerler $\mathrm{NO}_{3}$ için $50 \mathrm{mg} / \mathrm{L}, \mathrm{NO}_{2}$ için $\mathrm{WHO}$ (2011)'a göre $3 \mathrm{mg} / \mathrm{L}$ ve TSE266 (2005)'e göre 0,05 mg/L'dir. Aynı şekilde $\mathrm{NH}_{4}$ için WHO (2011) ve TSE266 (2005) tarafindan belirlenen sınır değer 0,05-0,50 $\mathrm{mg} / \mathrm{L}$ 'dir. $\mathrm{NO}_{3}, \mathrm{NO}_{2}$ ve $\mathrm{NH}_{4}$ konsantrasyonlarındaki mevsimsel değişim incelendiğinde kurak dönemde 
yağışlı döneme göre artış söz konusudur. Bu durum yağışların azalması ile birlikte tarımsal faaliyetler sonrasında toprak ve yeraltısularında gübre kaynaklı kirleticilerin birikimini göstermektedir (Varol ve Köse 2018b).

Çalışma alanına ait su örneklerinin As konsantrasyonu kurak dönemde $0,02-0,08 \mathrm{mg} / \mathrm{L}$ ve yağışlı dönemde ise $0,04-0,13 \mathrm{mg} / \mathrm{L}$ arasında değişmektedir. As için WHO (2011) ve TSE266 (2005) tarafindan belirlenen sinır değer 0,01 $\mathrm{mg} / \mathrm{L}$ 'dir. İçme suyu standartlarına göre çalışma alanındaki suların hepsi sınır değerin üzerinde Arsenik konsantrasyonlarına sahiptir. Bu durumda As içeriği bakımından bu suların içilmesi uygun değildir. As konsantrasyonlarındaki mevsimsel değişim incelendiğinde yă̆gşlı dönemde kurak dönem ile karşılaştırıldığında konsantrasyonlarda artış gözlemlenmektedir. Bu durum bölgede geniş bir yayılıma sahip Kızılcadağ ofiyolit ve melanj1 ile Marmaris peridotitleri içerisindeki Arsenik bulundurabilen kayaç türlerinin yeraltısuyu ile etkileşimine bağlı olduğu düşünülmektedir. Sulardaki bir diğer ağır metal Fe' dir. Kurak dönemde suların Fe konsantrasyonları $0-5,52 \mathrm{mg} / \mathrm{L}$ ve yağışl1 dönemde ise $0,01-0,30 \mathrm{mg} / \mathrm{L}$ arasında değişim göstermektedir. Sulardaki Fe iyonlarının varlığı hem jeojenik kökenli hem de antropojenik kökenli olabilmektedir. Çünkü Fe elementi doğal ortamda ve kayaçlarda bol miktarda bulunan bir elementtir. Sondaj kuyularından alınan örneklerdeki Fe iyonunun yüksek oluşu ise yine sondaj kuyusu ile su etkileşimine bağlı metal artışı olarak söylenebilmektedir. Kurak dönemde $\mathrm{Fe}$ iyon konsantrasyonlarında bir artış dikkati çekmektedir. Çalışma alanındaki sularda karşılaşılan bir diğer ağır metal ise Mn'dir. Mn konsantrasyonları kurak dönemde $0-0,35 \mathrm{mg} / \mathrm{L}$ ve yağışlı dönemde $0,01-0,09$ $\mathrm{mg} / \mathrm{L}$ arasındadır. Aynı şekilde kurak dönemde yağışlı döneme göre artış söz konudur.

\section{Hidrojeokimyasal Fasiyesler}

Hidrojeokimyasal fasiyesler, yeraltısuyunun kimyasal geçmişini ve kökenlerini belirlemek için kullanılan bir yöntemdir. Yeraltısuyu örneklerinin kimyasında baskın katyonlara ve anyonlara dayalı benzerlik ve farklılıkları göstermek için Piper (1944) tarafından geliştirilmiştir. Kurak ve yağışlı dönemlerde çalışma alanından toplanan su örneklerinin hidrojeokimyasal fasiyeslerini belirlemek için Piper (1944) diyagramı hazırlanmıştır. Piper diyagramına göre, kurak ve yağışlı dönemlerde $\mathrm{Ca}-\mathrm{Mg}-\mathrm{HCO}_{3}$ ve $\mathrm{Ca}-\mathrm{HCO}_{3}$ baskın su türleridir (Şekil 2). Çalışma alanında kurak dönemde sadece bir numune (S6) $\mathrm{Ca}-\mathrm{Na}-\mathrm{HCO}_{3}-\mathrm{Cl}$ $\mathrm{SO}_{4}$ su tipindedir. $\mathrm{Bu}$ örnek Dolomitik kireçtaşı ve Kızılcadağ ofiyolit ve melanjından oluşan Yuvadağ formasyonundan su alan sondaj kuyusuna aittir. $\mathrm{Bu}$ su örneğindeki $\mathrm{Na}$ ve $\mathrm{SO}_{4}$ iyonlarının artışı ofiyolitler ile kaya-su etkileşiminden kaynaklanmaktadır (Varol ve Köse 2018b).

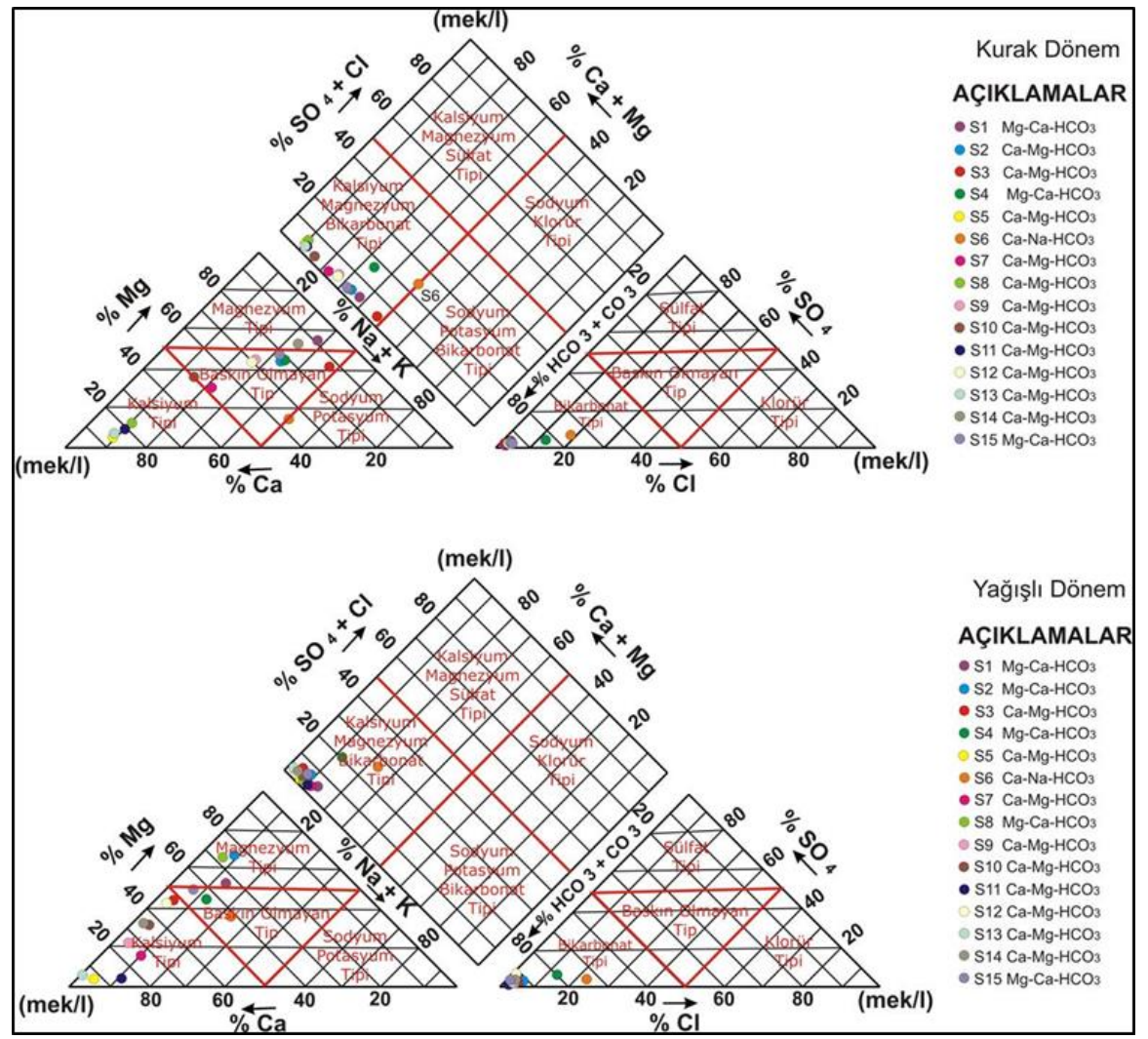

Şekil 2. Piper (1944) diyagramı üzerinde kurak ve yağışı dönemlerde su tipleri.

Figure 2.Water types in dry and wet periods on the Piper (1944) diagram. 


\section{İstatistiksel Analiz}

$\mathrm{Su}$ örneklerinin fizikokimyasal özellikleri arasındaki ilişkiyi belirlemek için korelasyon analizi uyguland 1 . Korelasyon analizi ile suyun mineraller ve kimyasal bileşenler arasındaki kimyasal prosesleri hakkında bilgi edinmek mümkündür (Varol ve Davraz 2015). Korelasyon analizinin sonuçları değerlendirilirken, korelasyon katsayısı 1 veya 1 'e yakınsa, iki değişken arasında iyi bir pozitif ilişki olduğu anlamına gelmektedir. Sifira yakın değerler $p$ $<0,05$ ise önemlidir. Yani, $r$ değeri $>0,7$ olan parametreler arasında güçlü bir korelasyon olduğu varsayılırken, $r$ değerinin 0,5 ile 0,7 arasinda orta derecede korelasyonlu olduğu söylenir (Kumar vd. 2006). Bu çalışmada da fizikokimyasal değişkenler ile eser elementler arasındaki potansiyel ilişkiyi değerlendirmek için "Pearson Korelasyon Analizi" (PCA) yapılmıştır. Tüm işlemler Windows için SPSS yazılım sürümü 15,0 kullanılarak gerçekleştirilmiştir. Ayrıca parametreler arasındaki ilişkilerdeki değişiklikleri incelemek için kurak ve yağışl1 dönemler için Pearson korelasyon matrisi ayrı ayrı uygulanmıştır (Tablo 4 ve 5).

Fizikokimyasal PCA sonuçlarına göre, T $\left({ }^{\circ} \mathrm{C}\right)$ yağışlı dönemde EC-TDS-K-Cl ile pozitif korelasyon gösterirken ve $\mathrm{NH}_{4}$ ile negatif korelasyon göstermiştir. Ek olarak, $\mathrm{T}\left({ }^{\circ} \mathrm{C}\right)$ parametre kurak dönemde $\mathrm{CO}_{3}$ iyonu ile negatif korelasyon göstermiştir. EC ve TDS yağışlı döneme $\mathrm{Mg}-\mathrm{Na}$ $\mathrm{HCO} 3-\mathrm{Cl}-\mathrm{SO}_{4}-\mathrm{NO}_{3}$ ile pozitif güçlü korelasyon gösterirken, kurak dönemde $\mathrm{NH}_{4}$ ile pozitif güçlü korelasyon göstermiştir. $\mathrm{pH}$, yağışl1 dönemde arsenik (As) ile pozitif güçlü korelasyon göstermiştir. $\mathrm{pH}$ kurak dönemde ise $\mathrm{CO}_{3}$ ve As ile pozitif güçlü korelasyon göstermiştir. Yağışlı ve kurak dönemlerin her ikisinde de ORP ile herhangi bir parametre arasında anlamlı bir ilişki gözlenmemiştir (Tablo 4 ve 5). Buna göre fizikokimyasal PCA sonuçları, çalışma alanındaki su kaynaklarında kaya-su etkileşiminin yanı sira evsel ve tarımsal atıklardan kaynaklanan noktasal ve yayılı kaynak kirliliğinin katkısını göstermektedir (Varol ve Köse 2018b).

Majör iyon PCA sonuçlarına göre $\mathrm{Mg}$, yağışlı dönemde $\mathrm{Na}-\mathrm{HCO}_{3}-\mathrm{Cl}-\mathrm{SO}_{4}-\mathrm{NO}_{3}$ ile pozitif ve güçlü korelasyon göstermiştir. Kurak dönemde ise $\mathrm{Mg}$, Na$\mathrm{K}-\mathrm{HCO}_{3}-\mathrm{Cl}-\mathrm{SO}_{4}$ ile pozitif ve güçlü korelasyon göstermiştir. $\mathrm{Mg}$ iyonunun diğer iyonlarla korelasyonu, Kızılcadağ ofiyolit ve melanjı içindeki dolomitik kireçtaşı ve magnezyum sülfatlı mineraller ile suyun etkileşimi ve çalışma alanındaki tarımsal süreçlerden etkilendiğini göstermektedir. Na yağışlı dönemde $\mathrm{HCO}_{3}-\mathrm{Cl}-\mathrm{SO}_{4}-\mathrm{NO}_{3}$ ile pozitif ve güçlü korelasyon gösterirken, kurak dönemde $\mathrm{K}-\mathrm{HCO}_{3}-\mathrm{Cl}$ $\mathrm{SO}_{4}$ ile pozitif ve güçlü korelasyon göstermiştir. $\mathrm{Su}$ içerisindeki $\mathrm{Na}$ iyonunun yüksekliği, kayaç oluşturan minerallerin doğal olarak ayrışmasını ve yeraltısuyu sistemindeki çeşitli iyon değişim süreçlerini göstermektedir (Davraz ve Özdemir 2014; Varol ve Davraz 2016; Varol ve Köse 2018b). Buna ek olarak, $\mathrm{Na}$ iyonunun $\mathrm{Cl}-\mathrm{SO}_{4}-\mathrm{NO}_{3}$ iyonlar1 ile korelasyonu ise çalışma alanında antropojenik bir kirliliğin varlığını göstermektedir. Su örneklerindeki $\mathrm{K}$ iyonu yağışılı dönemde $\mathrm{HCO}_{3}-\mathrm{Cl}-\mathrm{SO}_{4}-\mathrm{NO}_{3}$ ile pozitif korelasyon gösterirken, $\mathrm{NH}_{4}$ ile negatif korelasyon göstermiştir. Ayrıca bu parametre kurak dönemde $\mathrm{HCO}_{3}-\mathrm{Cl}-\mathrm{SO}_{4}$ ile yine pozitif korelasyon göstermektedir (Tablo 4). Su içerisindeki K iyonlarının yüksekliği $\mathrm{Na}$ iyonlarında olduğu gibi, kayaç oluşturan minerallerin doğal olarak ayrışmasını ve yeraltısuyu sistemindeki çeşitli iyon değişim süreçlerini göstermektedir. Buna ek olarak, $\mathrm{K}$ iyonlarının $\mathrm{Cl}-\mathrm{SO}_{4}-\mathrm{NO}_{3}$ iyonlar1 ile korelasyonu ise ortamdaki antropojenik kirliliği göstermektedir. Çalışma alanındaki sularda majör anyonların PCA sonuçlarına göre $\mathrm{HCO}_{3}$, kurak ve yağışlı dönemlerde $\mathrm{Cl}-\mathrm{SO}_{4}-\mathrm{NO}_{3}$ ile pozitif ve güçlü korelasyon göstermektedir. $\mathrm{Cl}$ iyonu da kurak ve yağışlı dönemlerde $\mathrm{SO}_{4}-\mathrm{NO}_{3}$ ile pozitif ve güçlü korelasyon göstermiştir. $\mathrm{SO}_{4}$ yağgşlı dönemde $\mathrm{NO}_{3}$ ile pozitif korelasyon gösterirken, kurak dönemde $\mathrm{SO}_{4}$ ile herhangi bir parametre arasında anlamlı bir ilişki gözlenmemiştir (Tablo 4 ve 5). Bu durum çalışma alanındaki antropojenik kirlilik ile açıklanabilir (Varol ve Davraz 2016; Varol ve Köse 2018b).

Ağır metal ve kirlilik parametrelerine göre PCA sonuçları, As yağışlı dönemde Mn ile pozitif ve güçlü korelasyon gösterirken $\mathrm{Fe}$ ile orta derecede korelasyon göstermiştir. Bu durum, yeraltısuyu-kaya etkileşimi ile suyun doğal hidrojeokimyasal evrimi ile açıklanabilir. Özellikle çalışma alanındaki litolojik birimlerden Kızılcadağ ofiyolit ve melanjına ait kaya ve minerallerin kimyasal ayrışma ve çözülmesi buna neden olabilir. Buna ek olarak suda arsenik, ortamdaki demirin indirgeyici çözünmesinden ve organik maddenin mikrobiyal oksidasyonundan da kaynaklanabilmektedir. Yağışlı dönemde $\mathrm{NO}_{3}$ ve herhangi bir parametre arasinda anlamlı bir ilişki gözlenmemiştir. Benzer şekilde, yağış̧1 dönemde $\mathrm{NO}_{2}$ 'in ve $\mathrm{Mn}$ 'ın diğer herhangi bir parametre arasında anlamlı bir ilişki gözlenmemiştir. Ancak kurak dönemde $\mathrm{NO}_{2}, \mathrm{NH}_{4}$ ile pozitif ve güçlü korelasyon göstermiştir (Tablo 4 ve 5 ). $\quad \mathrm{NO}_{2}$ iyonunun $\mathrm{NH}_{4}$ ile korelasyonu, çalışma alanındaki tarımsal kökenli antropojenik kirliliği desteklemektedir.

İstatistiksel PCA analiz sonuçlarına göre, çalışma alanındaki su kaynaklarının kimyasal bileşiminde, iklim koşulları, iyon değişim süreçlerine bağlı olarak kaya-su etkileşiminin ve su kaynaklarındaki antropojenik etkilerin önemli bir rolü bulunmaktadır. 
Tablo 4. Çalışma alanındaki suların kurak dönemde PCA sonuçları.

Table 4. PCA results of the waters in the study area in dry period.

\begin{tabular}{|c|c|c|c|c|c|c|c|c|c|c|c|c|c|c|c|c|c|c|c|c|}
\hline & & H & 물 & ) & $\underset{I}{U}$ & $\tilde{\hat{\theta}}$ & שึ & $\sum^{\infty}$ & z̃ & 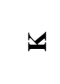 & $\overbrace{0}^{\infty}$ & ల & $\bar{U}$ & రి & $\stackrel{0}{2}$ & $\stackrel{0}{0}$ & $\vec{Z}$ & $\frac{n}{4}$ & $\Sigma$ & ت \\
\hline \multirow[t]{2}{*}{$\mathbf{T}$} & $\mathbf{r}$ & 1,00 &,- 28 &,- 35 & , 10 & ,10 &, 26 &, 35 & ,30 &, 18 & ,39 & $\begin{array}{l}-, 58 \\
\end{array}$ & ,24 & ,41 & $\begin{array}{l}-, 02 \\
\end{array}$ & ,37 & ,06 &,- 33 & ,088 & 27 \\
\hline & $\mathbf{p}$ & & ,31 &, 19 &, 71 &, 71 &, 33 &, 19 &, 26 & ,51 &, 14 &, 02 &, 37 &, 12 & 91 & ,16 &, 83 &, 22 & ,75 &, 31 \\
\hline \multirow[t]{2}{*}{ pH } & $\mathbf{r}$ & & 1,00 &, 31 &,- 40 &,- 40 &,- 75 &,- 47 &,- 47 &,- 67 & -84 &, 73 &,- 66 &,- 58 &,- 53 &,- 34 &,- 26 &,- 12 &, 34 &, 14 \\
\hline & $\mathbf{p}$ & & &, 24 & ,13 &, 13 &, 00 & ,07 & ,07 &, 00 & ,00 &, 00 & , 00 &, 02 &, 04 & 20 &, 34 & ,66 &, 20 & ,59 \\
\hline \multirow[t]{2}{*}{ ORP } & $\mathbf{r}$ & & & 1,00 &,- 27 &,- 27 &, 05 & ,00 &, 00 &,- 12 &,- 20 & $\begin{array}{l}, 63 \\
\end{array}$ &, 04 &,- 04 & ,09 &,- 47 &,- 20 & ,03 &,- 16 &,- 45 \\
\hline & $\mathbf{p}$ & & & &, 32 &, 32 & 85 & ,98 &, 97 & ,66 & ,46 &, 01 & 87 &, 87 &, 74 &, 07 & 47 & 89 &, 54 & ,08 \\
\hline \multirow[t]{2}{*}{$\mathbf{E C}$} & $\mathbf{r}$ & & & & 1,00 & 1,00 & 25 & ,50 & $\begin{array}{l}, 38 \\
\end{array}$ & ,25 & $\begin{array}{l}, 62 \\
\end{array}$ &,- 34 & ,51 & $\begin{array}{l}, 48 \\
\end{array}$ & 22 & $\begin{array}{l}, 57 \\
\end{array}$ & ,83 & ,28 &,- 12 & ,03 \\
\hline & $\mathbf{p}$ & & & & & &, 36 &, 05 &, 15 &, 35 & ,01 & ,20 & ,05 &, 06 &, 42 &, 02 & ,00 &, 31 & ,66 &, 89 \\
\hline \multirow[t]{2}{*}{ TDS } & $\mathbf{r}$ & & & & & 1,000 &, 25 & ,50 &, 38 &, 25 &, 62 &,- 34 &, 51 & ,48 &, 22 &, 57 &, 83 &, 28 &,- 12 &, 03 \\
\hline & $\mathbf{p}$ & & & & & & 36 & ,05 & , 15 & ,35 &, 01 & ,20 & ,05 & $\begin{array}{l}, 06 \\
\end{array}$ & 42 &, 02 &, 00 & ,31 & ,66 &, 89 \\
\hline \multirow[t]{2}{*}{$\mathbf{C a}$} & $\mathbf{r}$ & & & & & & 1,00 &, 25 & ,20 & ,46 & $\begin{array}{l}, 59 \\
\end{array}$ &,- 41 & ,46 &, 33 & ,58 & ,27 & ,10 &, 32 &,- 39 &,- 11 \\
\hline & $\mathbf{p}$ & & & & & & & 36 & ,46 &, 08 &, 01 &, 12 &, 08 & ,21 &, 02 &, 32 &, 70 & 23 &, 14 & ,67 \\
\hline \multirow[t]{2}{*}{ Mg } & $r$ & & & & & & & 1,00 & $\begin{array}{l}, 89 \\
\end{array}$ & ,53 &, 81 &,- 25 &, 82 & ,91 & ,45 &, 33 &, 44 &,- 18 & ,08 &,- 10 \\
\hline & $\mathbf{p}$ & & & & & & & &, 00 &, 04 &, 00 &, 36 &, 00 & ,00 &, 08 & ,21 & ,09 & .50 &, 76 &, 71 \\
\hline \multirow[t]{2}{*}{$\mathbf{N a}$} & $\mathbf{r}$ & & & & & & & & 1,00 &, 72 &, 70 &,- 20 &, 87 & ,96 & ,34 &, 29 &, 42 &,- 29 & 23 &,- 10 \\
\hline & $\mathbf{p}$ & & & & & & & & & 00 & ,00 &, 47 & ,00 & ,00 &, 21 &, 28 &, 11 & ,28 & 39 &, 72 \\
\hline \multirow[t]{2}{*}{ K } & $\mathbf{r}$ & & & & & & & & & 1,00 & ,61 &,- 35 & ,80 & ,68 & ,42 &, 23 &, 33 &,- 04 &,- 05 &,- 34 \\
\hline & $\mathbf{p}$ & & & & & & & & & &, 01 &, 19 & ,00 & ,00 &, 11 & 40 & 22 & 88 &, 84 &, 20 \\
\hline \multirow[t]{2}{*}{$\mathrm{HCO}_{3}$} & $\mathbf{r}$ & & & & & & & & & & 1,00 &,- 64 &, 83 &, 81 &, 53 &, 44 & 47 & ,01 &,- 23 &,- 15 \\
\hline & $\mathbf{p}$ & & & & & & & & & & & ,00 & 00 & 00 &, 03 &, 10 &, 07 & ,96 & ,39 & ,58 \\
\hline \multirow[t]{2}{*}{$\mathrm{CO}_{3}$} & $\mathbf{r}$ & & & & & & & & & & & 1,00 &,- 32 &,- 37 &,- 02 &,- 47 &,- 25 &, 05 &, 10 &,- 15 \\
\hline & $\mathbf{p}$ & & & & & & & & & & & & ,238 &, 16 & 93 &, 07 &, 35 & 85 &, 72 &, 58 \\
\hline \multirow[t]{2}{*}{$\mathbf{C l}$} & $r$ & & & & & & & & & & & & 1,00 &, 89 & ,58 &, 32 &, 47 &,- 09 &,- 13 &,- 37 \\
\hline & $\mathbf{p}$ & & & & & & & & & & & & & ,00 &, 02 &, 23 &, 07 &, 72 & ,62 &, 16 \\
\hline \multirow[t]{2}{*}{$\mathrm{SO}_{4}$} & $\mathbf{r}$ & & & & & & & & & & & & & 1,00 & ,32 & ,37 & ,46 &,- 24 & ,19 &,- 04 \\
\hline & $\mathbf{p}$ & & & & & & & & & & & & & &, 23 &, 17 &, 07 &, 37 &, 49 & .86 \\
\hline \multirow[t]{2}{*}{$\mathrm{NO}_{3}$} & $\mathbf{r}$ & & & & & & & & & & & & & & 1,00 &, 11 &, 01 &, 33 &,- 59 &,- 52 \\
\hline & $\mathbf{p}$ & & & & & & & & & & & & & & & ,68 & ,97 &, 22 &, 02 &, 04 \\
\hline \multirow[t]{2}{*}{$\mathrm{NO}_{2}$} & $\mathbf{r}$ & & & & & & & & & & & & & & & 1,0 &, 75 &,- 17 &, 26 &, 38 \\
\hline & $\mathbf{p}$ & & & & & & & & & & & & & & & &, 00 & ,53 & ,34 &, 15 \\
\hline \multirow[t]{2}{*}{$\mathbf{N H}_{4}$} & $\mathbf{r}$ & & & & & & & & & & & & & & & & 1,00 & $\begin{array}{l}-09 \\
\end{array}$ &, 18 &, 15 \\
\hline & $\mathbf{p}$ & & & & & & & & & & & & & & & & &, 73 &, 51 &, 57 \\
\hline \multirow[t]{2}{*}{ As } & $\mathbf{r}$ & & & & & & & & & & & & & & & & & 1,00 &,- 51 &,- 31 \\
\hline & $\mathbf{p}$ & & & & & & & & & & & & & & & & & & 04 &, 25 \\
\hline \multirow[t]{2}{*}{ Mn } & $r$ & & & & & & & & & & & & & & & & & & 1,00 &, 69 \\
\hline & $\mathbf{p}$ & & & & & & & & & & & & & & & & & & &, 00 \\
\hline \multirow[t]{2}{*}{$\mathbf{F e}$} & $\mathbf{r}$ & & & & & & & & & & & & & & & & & & & 1,00 \\
\hline & p & & & & & & & & & & & & & & & & & & & \\
\hline
\end{tabular}

Su Kalite Parametrelerinin Mevsimsel

\section{Değişimi}

\section{Suların İçe Suyu Özellikleri}

İnceleme alanındaki suların içme suyu olarak değerlendirilmesinde öncelikle Türk İçme Suyu (TSE 266) ve Dünya Sağl1k Örgütü (WHO 2011) standartları kullanılmıștır (Tablo 2). Havzadan alınan örneklerin genel olarak fiziksel özellikleri ve majör iyon içerikleri değerlendirildiğinde kurak ve yağışlı dönemde su örneklerinin tamamında $\mathrm{pH}$ değerleri içme suyu standartları tarafından belirlenen sınır değerlerin üzerinde tespit edilmiştir. TDS değerlerine göre yağışlı dönemde S4 ve S6 numaralı örnekler içme suyu standartlarınca belirlenen sınır değeri aşarken kurak dönemde sadece S4 numaralı örnekte sınır değer aşmıştır. Su örneklerinin $\mathrm{K}$ iyonu konsantrasyonu içme suyu standartları ile karşılaştırıldığında kurak ve yağışlı dönemlerin her ikisinde de sadece S6 numaralı örnekte sınır değer aşmaktadır. Aynı şekilde kurak ve yağışlı dönemlerde sadece $\mathrm{S} 4$ numaralı örnekte $\mathrm{HCO}_{3}$ iyonu konsantrasyonu bakımından sınır değerleri aştığ görülmektedir.

Majör iyonlar yanı sıra su örneklerinin diğer kirlilik parametreleri ile ağır metal içerikleri de Türk İçme Suyu (TSE 266) ve Dünya Sağlık Örgütü (WHO 2011) standartları ile değerlendirilmiştir (Tablo 2). Buna göre çalışma alanındaki su kaynaklarının $\mathrm{NO}_{3}$ ve $\mathrm{NO}_{2}$ konsantrasyonları sadece S4 sondaj kuyusundan alınan örnekte her iki dönemde sınır değerleri aşmaktadır. $\mathrm{NH}_{4}$ konsantrasyonu ise yine S4 sondaj kuyusundan alınan örnekte sadece kurak dönemde sınır değerin üzerindedir (Varol ve Köse 2018a). Arsenik (As) konsantrasyonları yağışlı ve kurak dönemlerin her ikisinde de tüm su örneklerinde Türk İçme Suyu 
(TSE 266) ve Dünya Sağlı Örgütü (WHO 2011) standartları tarafindan belirlenen sinır değerin üzerindedir. Mn konsantrasyonları ise kurak dönemde sadece S2 numaralı örnekte sinır değeri aşarken, yağışılı dönemde S4, S6, S7, S11, S12 ve S14 numaralı örneklerde sinır değerleri aşmaktadır. Sulardaki $\mathrm{Fe}$ konsantrasyonları ise kurak ve yağışı dönemlerde sadece S14 numaralı örnekte sınır değeri aşmaktadır. İçme suyu standartlarınca belirlenen sınır değeri aşan bu su örneklerinin içme suyu olarak kullanımı uygun değildir ve sağlığa zararlı etkileri olabilecektir. Çalışma alanındaki diğer tüm sular kurak dönemde içme suyu standartlarınca içilebilir özelliktedir. Ayrıca, çalışma alanındaki sular Schoeller içilebilirlik diyagramına göre değerlendirildiğinde tüm sular 'içilebilir özellikte sular' sınıfında yer almakla birlikte S4 ve S6 örnekleri sertlik değerleri bakımından 'orta kalitede içilebilir sular' sınıfında, diğer tüm sular 'iyi-çok iyi kalitede içilebilir sular' sınıfındadır (Şekil 3, Köse 2017).

Tablo 5. Çalışma alanındaki suların yağışlı dönemde PCA sonuçları.

Table 5. PCA results of the waters in the study area in wet period.

\begin{tabular}{|c|c|c|c|c|c|c|c|c|c|c|c|c|c|c|c|c|c|c|c|}
\hline & & $\mathbf{T}$ & pH & ORP & EC & TDS & $\mathbf{C a}$ & $\mathbf{M g}$ & $\mathrm{Na}$ & $\mathbf{K}$ & $\mathrm{HCO}_{3}$ & $\mathrm{CO}_{3}$ & $\mathrm{Cl}$ & $\mathrm{SO}_{4}$ & $\mathrm{NO}_{3}$ & $\mathrm{NH}_{4}$ & As & Mn & $\mathbf{F e}$ \\
\hline \multirow[t]{2}{*}{$\mathbf{T}$} & $\mathbf{r}$ & 1,00 &,- 50 & $\begin{array}{l}, 08 \\
\end{array}$ & ,59 & $\begin{array}{l}, 59 \\
\end{array}$ & ,47 & ,29 & ,34 & ,61 &, 45 &,- 17 & $\begin{array}{l}, 53 \\
\end{array}$ & ,37 & ,28 &,- 72 &, 41 & ,48 &,- 03 \\
\hline & p & & ,05 &, 75 & ,02 & ,02 & ,07 & ,28 & ,21 & ,01 & ,09 &, 52 & ,03 & , 17 &, 30 & ,00 &, 12 & ,07 & ,90 \\
\hline \multirow[t]{2}{*}{ pH } & $\mathbf{r}$ & & 1,00 &,- 62 & $\begin{array}{l}-55 \\
\end{array}$ & \begin{tabular}{|l|}
,- 55 \\
\end{tabular} & \begin{tabular}{|l|}
,- 64 \\
\end{tabular} &,- 25 &,- 23 & \begin{tabular}{|l|}
,- 43 \\
\end{tabular} & \begin{tabular}{l|}
-43 \\
\end{tabular} & ,60 &,- 46 &,- 30 & \begin{tabular}{|c|}
,- 54 \\
\end{tabular} & ,42 & \begin{tabular}{|l|}
,- 59 \\
\end{tabular} &,- 46 &,- 02 \\
\hline & $\mathbf{p}$ & & & ,01 &, 03 & ,03 & ,01 & ,36 & ,39 & , 10 & ,10 & ,01 & ,08 & 26 & ,03 & ,11 & ,02 & ,08 & 93 \\
\hline \multirow[t]{2}{*}{ ORP } & $\mathbf{r}$ & & & 1,00 &, 13 &, 13 & ,32 &,- 11 & ,01 & ,21 &,- 03 &,- 35 & ,11 &,- 04 & ,19 &,- 00 & ,39 & ,41 & ,02 \\
\hline & $\mathbf{p}$ & & & & ,62 & ,62 & ,23 & 68 & ,97 & ,44 & ,90 & ,20 & ,67 & ,86 & ,49 & $\begin{array}{l}, 98 \\
\end{array}$ & ,14 & ,12 & ,91 \\
\hline \multirow[t]{2}{*}{$\mathbf{E C}$} & $\mathbf{r}$ & & & & 1,00 & 1,00 &, 52 &, 82 &, 83 &, 60 &, 86 &,- 02 &, 86 &, 88 &, 80 &,- 54 &, 21 & ,09 &,- 05 \\
\hline & $\mathbf{p}$ & & & & & &, 04 & , 00 & , 00 & ,01 &, 00 & ,92 &, 00 & ,00 & ,00 &, 03 & ,44 & ,72 & ,83 \\
\hline \multirow[t]{2}{*}{ TDS } & $\mathbf{r}$ & & & & & 1,00 &, 52 &, 82 &, $\mathbf{8 3}$ & ,60 &, 86 &,- 02 & ,86 & $\mathbf{8 8}$ & ,80 &,- 54 & ,21 & ,09 &,- 05 \\
\hline & $\mathbf{p}$ & & & & & &, 04 & ,00 & , 00 & ,01 & ,00 & 92 & ,00 & ,00 & ,00 & ,03 & ,44 & ,72 & 83 \\
\hline \multirow[t]{2}{*}{$\mathrm{Ca}$} & $\mathbf{r}$ & & & & & & 1,00 &, 25 &, 36 & ,69 &, 52 &,- 30 & ,68 &, 41 &, 54 &,- 26 &, 41 &, 36 &,- 23 \\
\hline & $\mathbf{p}$ & & & & & & & ,36 & ,17 & ,00 & ,04 & ,26 & ,00 &, 12 &, 03 &, 33 &, 12 & , 18 & ,40 \\
\hline \multirow[t]{2}{*}{$\mathbf{M g}$} & $\mathbf{r}$ & & & & & & & 1,00 &, 93 & ,50 &, 87 &, 24 & ,79 &, 93 &, 75 &,- 39 &,- 07 &,- 22 & $\begin{array}{l}-, 04 \\
\end{array}$ \\
\hline & $\mathbf{p}$ & & & & & & & & ,00 & ,05 & , 00 &, 37 & ,00 & ,00 & ,00 & ,14 & ,78 & ,41 & 88 \\
\hline \multirow[t]{2}{*}{$\mathrm{Na}$} & $\mathbf{r}$ & & & & & & & & 1,00 &, 59 & ,78 &, 37 &, 82 & ,96 &, 75 &,- 29 & ,04 &,- 08 &,- 04 \\
\hline & $\mathbf{p}$ & & & & & & & & &, 02 & , 00 &, 17 & ,00 & ,00 & ,00 & ,28 & ,87 &, 75 & 87 \\
\hline \multirow[t]{2}{*}{$\mathbf{K}$} & $\mathbf{r}$ & & & & & & & & & 1,00 & ,62 &,- 17 &, 84 & ,61 & ,58 &,- 64 &, 25 & ,19 &,- 05 \\
\hline & $\mathbf{p}$ & & & & & & & & & & ,01 &, 53 & ,00 & ,01 &, 02 & ,01 &, 36 & ,48 & 85 \\
\hline \multirow[t]{2}{*}{$\mathrm{HCO}_{3}$} & $\mathbf{r}$ & & & & & & & & & & 1,00 &,- 09 & $\mathbf{, 8 8}$ &, $\mathbf{8 3}$ &, $\mathbf{8 3}$ &,- 58 &,- 01 &,- 08 &,- 18 \\
\hline & $\mathbf{p}$ & & & & & & & & & & & ,74 & ,00 & ,00 & ,00 & , 02 & ,96 & ,75 & ,51 \\
\hline \multirow[t]{2}{*}{$\mathrm{CO}_{3}$} & $\mathbf{r}$ & & & & & & & & & & & 1,00 & ,00 &, 25 &,- 07 & ,44 &,- 19 &,- 26 &, 15 \\
\hline & $\mathbf{p}$ & & & & & & & & & & & & ,98 & ,36 & ,79 & ,09 & ,49 &, 33 &, 57 \\
\hline \multirow[t]{2}{*}{$\mathbf{C l}$} & $\mathbf{r}$ & & & & & & & & & & & & 1,00 & ,87 &, 81 &,- 52 &, 14 &, 02 &,- 12 \\
\hline & $\mathbf{p}$ & & & & & & & & & & & & & ,00 & ,00 & ,04 & ,59 & ,91 & ,65 \\
\hline \multirow[t]{2}{*}{$\mathrm{SO}_{4}$} & $\mathbf{r}$ & & & & & & & & & & & & & 1,00 &, 82 &,- 34 &, 07 &,- 08 &,- 04 \\
\hline & $\mathbf{p}$ & & & & & & & & & & & & & & , 00 & ,20 & ,78 & ,75 & 87 \\
\hline \multirow[t]{2}{*}{$\mathrm{NO}_{3}$} & $\mathbf{r}$ & & & & & & & & & & & & & & 1,00 &,- 32 &, 31 & ,13 & ,12 \\
\hline & $\mathbf{p}$ & & & & & & & & & & & & & & & ,24 & ,26 & ,62 & ,65 \\
\hline \multirow[t]{2}{*}{$\mathbf{N H}_{4}$} & $\mathbf{r}$ & & & & & & & & & & & & & & & 1,00 &,- 09 &,- 09 &,- 00 \\
\hline & $\mathbf{p}$ & & & & & & & & & & & & & & & & ,73 & ,74 & ,98 \\
\hline \multirow[t]{2}{*}{ As } & $\mathbf{r}$ & & & & & & & & & & & & & & & & 1,00 & ,86 &, 61 \\
\hline & $\mathbf{p}$ & & & & & & & & & & & & & & & & & ,00 & ,01 \\
\hline \multirow[t]{2}{*}{ Mn } & $\mathbf{r}$ & & & & & & & & & & & & & & & & & 1,00 &, 33 \\
\hline & $\mathbf{p}$ & & & & & & & & & & & & & & & & & & ,21 \\
\hline \multirow[t]{2}{*}{$\mathbf{F e}$} & $\mathbf{r}$ & & & & & & & & & & & & & & & & & & 1,00 \\
\hline & $\mathbf{p}$ & & & & & & & & & & & & & & & & & & $\cdot$ \\
\hline
\end{tabular}



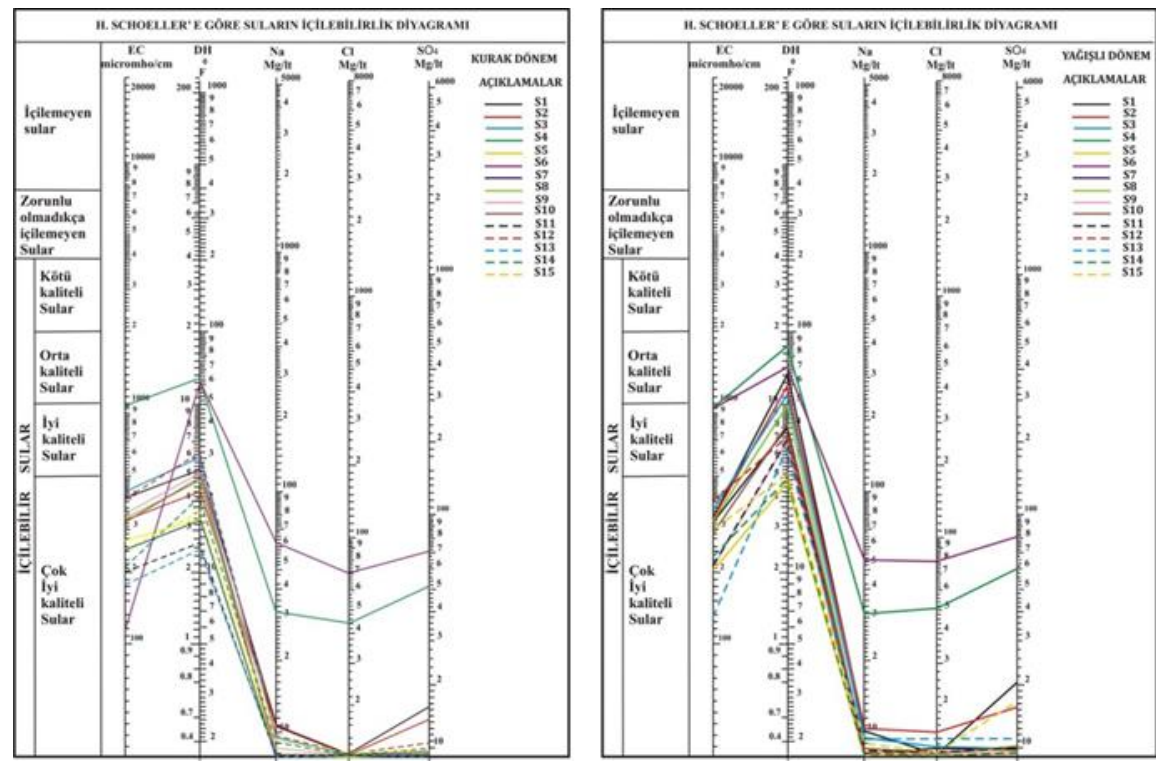

Şekil 3. Schoeller içilebilirlik diyagramına göre kurak ve yağışlı dönemlerde su örneklerinin sınıflandırılması.

Figure 3.Classification of water samples in dry and wet periods according to the Schoeller diagram.

\section{Sulartn Sulama Suyu Olarak Kullantm Özellikleri}

Suların sulama suyu olarak kullanılabilirliğinin belirlenmesi ve mevsimsel değişiminin değerlendirilmesinde kurak ve yağışlı dönemler için ayrı ayrı hazırlanan ABD Tuzluluk Laboratuvarı ve Wilcox diyagramları kullanılmıştır (Şekil 4 ve 5). ABD Tuzluluk Laboratuvarı diyagramı suların EC $(\mu \mathrm{S} / \mathrm{cm})$ değeri ile SAR (Sodyum Adsorbsiyon Oranı) arasındaki ilişkiye bağlı olarak oluşturulmaktadır. ABD Tuzluluk Laboratuvarı diyagramına göre çalışma alanındaki suların çoğu kurak dönemde C1S1 (Az tuzlu ve Az sodyumlu) ve
C2S1 (Orta tuzlulukta ve Az sodyumlu) sular sınıfinda sadece S4 no'lu örnek C3S1 (Yüksek tuzlu ve Az sodyumlu) sinifindadır (Varol ve Köse 2018a). Yağıșli dönemde ise S4 no'lu örnek C3S1 (Yüksek tuzlu ve Az sodyumlu), S6 no'lu örnek C3S2 (Yüksek tuzlu ve Orta sodyumlu) sular sınıfinda bulunmaktadır. Diğer tüm örnekler yağışlı dönemde de C1S1 (Az tuzlu ve $\mathrm{Az}$ sodyumlu) ve C2S1 (Orta tuzlulukta ve $\mathrm{Az}$ sodyumlu) sular sınıfinda yer almaktadır (Şekil 4). $\mathrm{Bu}$ diyagrama göre her iki dönemde de $\mathrm{S} 4$ ve S6 no'lu örneklerin sulama suyu olarak kullanımı sinırlidir.
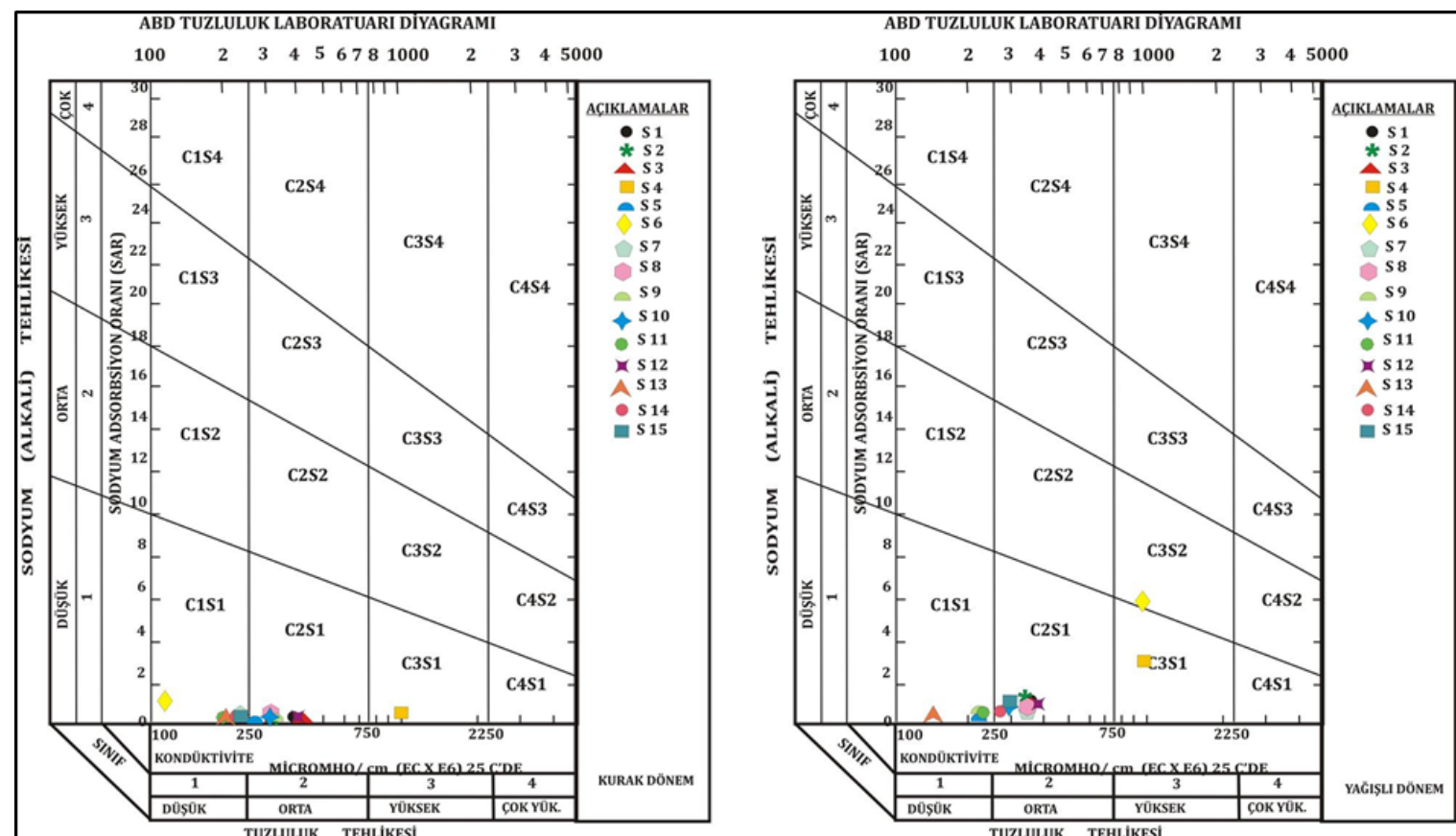

Şekil 4. ABD Tuzluluk Laboratuvarı diyagramına göre kurak ve yağışlı dönemlerde suların sınıflandırılması.

Figure 4. Classification of waters in dry and wet periods according to the U.S.A. Salinity Laboratory diagram. 


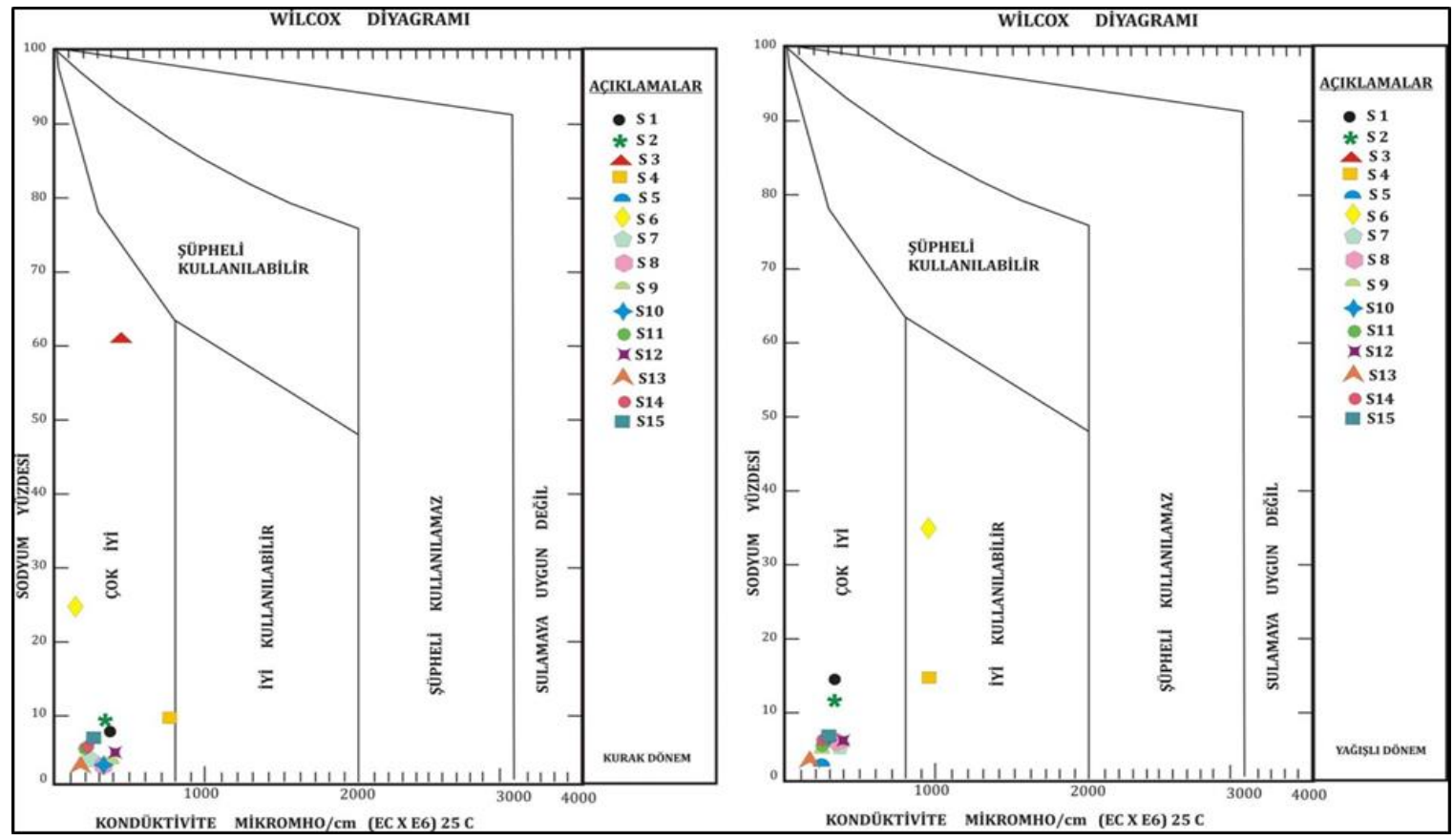

Şekil 5. Wilcox diyagramına göre kurak ve yağışlı dönemde suların sınıflandırılması.

Figure 5.Classification of waters in dry and wet periods according to Wilcox diagram.

Wilcox diyagram 1 da sulama suyu sınıflandırmasında kullanılmakta olan bir başka yöntemdir. Bu diyagramda ise suların EC $(\mu \mathrm{S} / \mathrm{cm})$ değeri ile $\% \mathrm{Na}$ değerleri kullanılmakta ve bu iki parametre arasındaki ilişkiye bağlı olarak bir sinıflandırma yapılmaktadır. Wilcox diyagramına göre kurak dönemde çalışma alanındaki tüm sular 'Çok Iyi Kullanilabilir Sular' sinıfinda yer almaktadır (Şekil 5) (Varol ve Köse 2018a). Yağışlı dönemde ise S4 ve S6 no'lu örnekler "Iyi Kullanabilir Sular" sinıfindadir.

Sodyum adsorbsiyon oranı (SAR), sulama suyu olarak kullanıma uygunluğun belirlenmesinde en çok yararlanılan ölçütlerden biridir. Bu sınıflandırmada SAR $<10$ ise "çok iyi özellikte sulama suları", 10-18 arasında ise "Iyi özellikte sulama suları", 18-26 arasında ise "Orta özellikte sulama sularl" ve SAR> 26 ise "Kötü özellikte sulama suları" sinıfinda yer almaktadır (Şahinci 1991). İnceleme alanında SAR değerleri kurak dönemde 0,44 ile 6,36 arasında değişmektedir (Varol ve Köse 2018a). Yağışl1 dönemde ise 0,22 ile 5,92 arasindadır. Buna göre çalışma alanı genelindeki sular her iki dönemde de "Çok iyi özellikte sulama suları" sınıfındadır.

\section{Tartışma ve Sonuç}

$\mathrm{Bu}$ çalışmada Yazır Gölü havzasındaki su kaynaklarının hidrojeokimyasal ve kalite özelliklerinin mevsimsel değişimi ve kullanılabilirliği incelenmiştir. Yazır Gölü sulak alan havzası Burdur Gölü Kapalı Havzasının bir alt havzası olup çoğunluğu Burdur ili Çavdır ilçe sınırları içerisinde yer almaktadır. Söz konusu araştırma alanı ile ilgili olarak detaylı ve güncel hidrojeolojik ve hidrojeokimyasal araştırmalar bulunmamaktadır. $\mathrm{Bu}$ nedenle bu çalışma, aynı zamanda bir sulak alan özelliğine sahip Yazır Gölü havzasında sürdürülebilir su yönetimi ve su kalitesine bağlı kullanımı açısından önem taşımaktadır.

Çalışma alanındaki litolojik birimler alttan üstte doğru Yeşilbarak napı, Likya napları, paraallokton ve neootokton konumlu kaya birimlerinden oluşmaktadır. Çalışma alanındaki litolojik birimler fiziksel özellikleri ve akifer olabilme özelliklerine göre taneli ortam akiferi (Akf-1), erimeli-çatlaklı kaya ortam akiferi (Akf-2), akitard ortam-1 (Akt-1) ve akifüj ortam (Akj) olarak ayırtlanmıştır. Bölgede en önemli akifer birim alüvyon ve kireçtaşlarıdır.

Çalışmada kurak ve yağışlı dönemlerde kuyu, kaynak, dere ve göl suyundan alınan toplam 30 su örneği analiz edilmiştir. $\mathrm{Su}$ örneklerinin hidrojeokimyasal özellikleri ve su tiplerini belirlemek için bir Piper diyagramı kullanılmıştır. Buna göre, çalışma alanında $\mathrm{Ca}-\mathrm{Mg}-\mathrm{HCO}_{3}$ ve $\mathrm{Ca}-$ $\mathrm{HCO}_{3}$ kurak ve yağgşlı dönemlerde gözlenen hakim su türleridir. Genel olarak, çalışma alanında su örneklerinde kalsiyum ve bikarbonat iyonları hakimdir. Su örneklerinin kimyasal bileşimi kaya-su etkileşiminden güçlü bir şekilde etkilenmektedir. Çalışma alanında, sadece bir örnekte $\mathrm{Na}$ ve $\mathrm{SO}_{4}$ iyonlarının artışı belirlenmiştir. $\mathrm{Bu}$ artış çalışma alanında geniş alanlarda yüzeyleyen Kızılcadă ofiyolitleri ile ve su kaynaklarına tarımsal kökenli antropojenik girdilerle ilişkilendirilmiştir. Çalışmada ayrıca su örneklerine ait Hidrokimyasal parametreler arasındaki ilişkiyi tanımlamak için Pearson Korelasyon Analizi (PCA) yapıldı. Buna göre, bazı parametreler arasında orta-güçlü korelasyon olduğu 
belirlenmiştir $(r<0,7)$. PCA sonuçlarına göre çalışma alanındaki suyun jeokimyasal bileşimini etkileyen iki ana proses olduğu belirlenmiştir. Bunlar ayrışma süreçleri ve antropojenik girdilerdir. İstatistiksel analizlere göre, su örneklerinin EC ve TDS değerlerindeki artışlar, tarımsal faaliyetlerden kaynaklanan azot türevleri ile ilişkilidir. Ayrıca Na, $\mathrm{Fe}, \mathrm{SO}_{4}$ ve $\mathrm{Mg}$ arasında da pozitif korelasyon olduğu belirlenmiştir. $\mathrm{Bu}$ durum, özellikle $\mathrm{Mg}$ artışının Kızılcadağ ofiyolitik melanjı ile ilişkili olarak kayasu etkileşiminden kaynaklandığını düşündürmektedir.

$\mathrm{Su}$ örneklerinin analiz sonuçları WHO (2011) ve TSE266 (2005) tarafından belirlenen içme suyu standartlarıyla karşılaştırıldığında, özellikle S4 ve S6 numaralı sondaj kuyusuna ait örnekte her iki dönemde majör iyonlardan $\mathrm{HCO}_{3}$, kirlilik parametrelerinden $\mathrm{NO}_{3}, \mathrm{NO}_{2}$ ve $\mathrm{NH}_{4}$ iyonlarının kritik değerlerin üzerinde olduğu bunun yanı sıra ağır metal konsantrasyonları (As, Fe ve Mn) bakımından ise As konsantrasyonları yağışlı ve kurak dönemlerin her ikisinde de tüm su örneklerinde belirlenen sınır değerin üzerindedir. Mn konsantrasyonları ise kurak dönemde sadece S2 numaralı örnekte sinır değeri aşarken, yağışlı dönemde S4, S6, S7, S11, S12 ve S14 numaralı örneklerde sınır değerleri aşmaktadır. Fe konsantrasyonları ise kurak ve yağışlı dönemlerde sadece S14 numaralı örnekte sınır değeri aşmaktadır. $\mathrm{Bu}$ durum göstermektedir ki su kaynaklarının içme suyu olarak kullanımı ağır metaller açısından sağlığa zararlı etkiler yaratabilecektir. Schoeller içilebilirlik diyagramına göre de çalışma alanındaki S4 ve S6 numaralı örnekler içme suyu olarak kullanıma uygun değildir.

Çalışma alanındaki suların sulama suyu olarak kullanılabilirliğinin değerlendirilmesi ve kalitesinin belirlenmesi için ABD Tuzluluk Laboratuvarı, Wilcox diyagramları ve SAR siniflaması kullanılmıştır. ABD Tuzluluk Laboratuvarı diyagramına göre her iki dönemde de S4 ve S6 numaralı örneklerin sulama suyu olarak kullanımı sinırlıdır. Wilcox diyagramına göre kurak dönemde çalışma alanındaki tüm sular 'Çok İyi Kullanılabilir Sular' sınıfında yer almaktadır. Yağışılı dönemde ise S4 ve S6 numaralı örnekler "İyi Kullanabilir Sular" sinıfindadır. Ayrıca sulama suyu kriterlerinden biri olan SAR değerlerine göre yapılan değerlendirmeye göre ise çalışma alanı genelindeki sular her iki dönemde de "Çok iyi özellikte sulama suları" sinifindadır.

Sonuç olarak bu çalışmada Yazır Gölü havzası yüzey ve yeraltı su kaynaklarındaki ağır metal ve azot ve türevi bileşenlerle ilişkili kirlilik nedeni ile içme suyu olarak kullanımı sağlığa etkisi açısından uygun olmayıp sadece sulama suyu olarak kullanıma uygun olduğu belirlenmiştir.

\section{Teșekkür}

Yazarlar, 4455-YL1-15 numaral1 proje ile araştırmanın yapılmasını destekleyen Süleyman Demirel Üniversitesi Bilimsel Araştırma Projeleri birimine teşekkür ederler.

\section{Kaynaklar}

Akkan T, Yazicioglu O, Yazici R, Yilmaz M. 2018. Assessment of irrigation water quality of Turkey using multivariate statistical techniques and water quality index: Siddıklı Dam Lake. Desalin Water Treat. 115:261-270. doi: $10.5004 /$ dwt.2018.22302

Alam MO, Shaikh WA, Chakraborty S, Avishek K, Bhattacharya T. 2016. Groundwater arsenic contamination and potential health risk assessment of Gangetic Plains of Jharkhand, India. Expos Health. 8(1):125-142. doi: $10.1007 / \mathrm{s} 12403-015-0188-0$

APHA 1998. American Public Health Association. Standard Methods for the Examination of Water and Wastewater. Washington DC: American Public Health Association 1325 p.

Bilgin ZR, Karaman T, Öztürk Z, Şen MA, Şenel M. 1990. Yeşilova-Acıgöl Civarının Jeolojisi Raporu. Ankara: MTA. Rapor No: 9429

Chave P. 2001. The EU water framework directive. London: IWA publishing $208 \mathrm{p}$.

Çapan U. 1980. Toros Kuşağı Ofiyolit Masiflerinin(Marmaris, Mersin, Pozantı, Pınarbaşı ve Divriği) İç Yapıları, Petrolojisi ve Petrokimyalarına Yaklaşımlar. [Doktora Tezi]. Hacettepe Üniversitesi. $400 \mathrm{~s}$.

Davraz A, Özdemir A. 2014. Groundwater quality assessment and its suitability in Çeltikçi plain (Burdur/Turkey). Environ Earth Sci. 72:1167-1190. doi: 10.1007/s12665-013-3036-1

Davraz A, Şener Ş, Şener E. 2016. Su Kaynaklarının Kullanma Ve Koruma Metodolojisinin Geliştirilmesi: Eğirdir Gölü Havzası Örneği. Mühendislik Bilimleri ve Tasarım Dergisi, 4(3):227-238. doi: 10.21923/jesd.71639

Erakman B, Meşhur M, Gül MA, Alkan H, Öztaş Y, Akpınar M. 1982. Toros projesine bağlı KalkanKöyceğiz- Çameli-Tefenni arasında kalan alanın jeolojisi ve hidrokarbon olanakları raporu. Akara: TPAO. Rapor No: 1732.

Jeong CH. 2001. Effect of land use and urbanization on hydrochemistry and contamination of groundwater from Taejon area, Korea. J Hydrol. 253(1-4):194-210. doi: 10.1016/S0022-1694(01)00481-4

Karadavut S. 2009. Aksaray bölgesi yer üstü ve yeraltı su kaynaklarının potansiyeli kalitesi ve etkin sulama açısından değerlendirilmesi. [Doktora Tezi]. Namık Kemal Üniversitesi. 77 s.

Kıymaz S, Karadavut U, Ertek A. 2016. Seyfe gölü havzası yer altı suyu kalitesinin zamana göre değişimin incelenmesi. Uludağ Üniversitesi Ziraat Fakültesi Dergisi. 30(1):21-31.

Koçyiğit A, Ünay E, Saraç G. 2000. Episodic graben formation and extensional neotectonic regime in west 
central Anatolia and the Isparta angle: a case study in the Akşehir-Afyon graben, Turkey. Geol Soc Spec Publ. 173:405-421.

doi: 10.1144/GSL.SP.2000.173.01.19

Köse İ. 2017. Yazır Gölü (Çavdır/Burdur) Sulak Alan Havzasının Hidrojeoloji ve Hidrojeokimyasal İncelemesi. [Yüksek Lisans Tezi]. Süleyman Demirel Üniversitesi. $117 \mathrm{~s}$.

Kumar M, Ramanathan AL, Rao MS, Kumar B. 2006. Identification and evaluation of hydrogeochemical processes in the groundwater environment of Delhi, India. Environ Geol. 50:1025-1039.

doi: 10.1007/s00254-006-0275-4

Kumar SK, Babu SH, Rao PE, Selvakumar S, Thivya C, Muralidharan S, Jeyabal G. 2016. Evaluation of wat er quality and hydrogeochemistry of surface and groundwater, Tiruvallur District, Tamil Nadu, India. Applied Water Science. 7:2533-2544. doi: 10.1007/s13201-016-0447-7

Makwe E, Chup CD. 2013. Seasonal variation in physicochemical properties of groundwater around Karu Abattorr. Ethiopian Journal of Environmental Studies and Management. 6(5):489-497. doi: 10.4314/ejesm.v6i5.6

Meşhur M, Yoldemir O, Akpınar M, Öztaş Y, Alkan H. 1989. Batı Toroslar'1n Jeolojisi ve Petrol Olanakları Raporu. Ankara: TPAO.

Mutlu T, Verep B. 2018. The Water Quality of Streams Flowing Into South Eastern Black Sea Coasts In Terms Of Physico-Chemical Properties. Fresen Environ Bull. 27(5A):3752-3758.

Ngabirano H, Byamugisha D, Ntambi E. 2016. Effects of seasonal variations in physical parameters on quality of gravity flow water in Kyanamira Sub-County, Kabale District, Uganda. Journal of Water Resource and Protection. 8(13):1297-1309. doi: 10.4236/jwarp.2016.813099

Oinam JD, Ramanathan AL, Linda A, Singh G. 2011. A study of arsenic, iron and other dissolved ion variations in the groundwater of Bishnupur District, Manipur. India. Environ Earth Sci. 62:1183-1195. doi: 10.1007/s12665-010-0607-2

Piper AM. 1944. A graphic procedure in the chemical interpretation of water analysis. EOS T Am Geophys Un. 25(6):914-928. doi: 10.1029/TR025i006p00914

Poisson A. 1977. Recherces geologiques dans les Taurides occidentales (Turquie). [PhD Thesis]. Paris-Sud University. 795 p.

Rainbow PS. 1995. Biomonitoring of heavy metal availability in the marine environment. Mar Pollut Bull. 31(4-12):183-192. doi: 10.1016/0025-326X(95)00116-5

Ranjan RK, Ramanathan AL, Parthasarthy P, Kumar A. 2013. Hydrochemical characteristics of groundwater in the plains of Phalgu River in Gaya, Bihar, India. Arab J Geosci. 6:3257-3267. doi: 10.1007/s12517-012-0599-1

EPC 2000. European Parliament and Council 2000. Directive 2000/60/EC of the European Parliament and of the Council of 23 October 2000 establishing a framework for Community action in the field of water policy. Official Journal of the European Communities. L327:1-73.

Sönmez AY, Hisar O, Karataş M, Arslan G, Aras MS. 2008. Sular Bilgisi. Ankara: Nobel Akademik Yayıncilık 202 s.

Sönmez A, Hisar O, Yanık T. 2012. Karasu Irmağında ağır metal kirliliğinin tespiti ve su kalitesine göre sinıflandırılması. Atatürk Üniversitesi Ziraat Fakültesi Dergisi. 43(1): 69-77.

Subramani T, Elango L, Damodarasamy SR. 2005. Groundwater quality and its suitability for drinking and agricultural use chithar River Basin, Tamil Nadu, India. Environ Geol. 47:1099-1110. doi: 10.1007/s00254-005-1243-0

Şahinci A. 1991. Doğal Suların Jeokimyası. İzmir: Reform Matbaas1 $548 \mathrm{~s}$.

Şenel M, Selçuk H, Bilgin ZR, Şen AM, Karaman T, Dinçer MA, Durukan E, Arbas A, Örçen S, Bilgi C. 1989. Çameli (Denizli)- Yeşilova (Burdur)- Elmalı (Antalya) ve kuzeyinin jeolojisi. Ankara: MTA. Rapor No: 9429.

TSE266 2005. İnsani tüketim amaçlı sular, Türk İçme Suyu Standartları TS 266 sayılı standart-Türk Standartları Enstitüsü-Ankara.

Varol S, Davraz A. 2015. Evaluation of the groundwater quality with WQI (water quality index) and multivariate analysis: a case study of the Tefenni plain (Burdur/Turkey). Environ Earth Sci. 73:17251744. doi: $10.1007 / \mathrm{s} 12665-014-3531-\mathrm{z}$

Varol S, Davraz A. 2016. Evaluation of potential human health risk and investigation of drinking water quality in Isparta city center (Turkey). J Water Health. 14(3):471-488. doi: 10.2166/wh.2015.187

Varol S, Köse İ. 2018a. Yazır Gölü (Çavdır/Burdur) Sulak Alan Havzasının Hidrojeoloji ve Hidrojeokimyasal İncelemesi. Karaelmas Science and Engineering Journal. 8(1):156-167. doi: $10.7212 \% 2 F z k u f b d . v 8 i 1.924$

Varol S, Köse I. 2018b. Effect on human health of the arsenic pollution and hydrogeochemistry of the Yazır Lake wetland (Çavdır-Burdur/Turkey). Environ Sci Pollut R. 25(16):16217-16235. doi: $10.1007 / \mathrm{s} 11356-018-1815-7$

WHO 2011. Guidelines for drinking-water quality, 4th edition. Geneva, Switzerland: World Health Organization $541 \mathrm{p}$.

WWAP 2012. World Water Assessment Programme. The United Nations World Water Development Report 4: Managing Water under Uncertainty and Risk. Paris: UNESCO 357. p. 